Article

\title{
Underground Morphological Detection of Ground Fissures in Collapsible Loess Area Based on Three-Dimensional Laser Scanning Technology
}

\author{
Yibo He ${ }^{1}\left(\mathbb{D}\right.$, Zhenqi Hu ${ }^{2, *(\mathbb{D})}$, Yaokun Fu ${ }^{1} \mathbb{D}$, Kun Yang ${ }^{1} \mathbb{D}^{\mathbb{D}}$, Rui Wang ${ }^{2,3}$, Guomou Shi $^{1}$, Zhanjie Feng ${ }^{2}$, \\ Qirang Yang ${ }^{2}$ and Liang $\mathrm{Yu}^{1}$
}

1 Institute of Land Reclamation and Ecological Restoration, China University of Mining and Technology, Beijing 100083, China; heyibo@student.cumtb.edu.cn (Y.H.); bqt1800204043@student.cumtb.edu.cn (Y.F.); bqt1800204056@student.cumtb.edu.cn (K.Y.); SQT1900204092@student.cumtb.edu.cn (G.S.); zqt1900204094g@student.cumtb.edu.cn (L.Y.)

2 School of Environment Science and Spatial Informatics, China University of Mining and Technology, Xuzhou 221116, China; r-wang@cumt.edu.cn (R.W.); fengzhanjie@cumt.edu.cn (Z.F.); ts19160068a31@cumt.edu.cn (Q.Y.)

3 College of Resources and Architecture, Gannan University of Science and Technology, Ganzhou 341000, China

* Correspondence: huzq@cumtb.edu.cn; Tel.: +86-1516-218-9270

check for updates

Citation: He, Y.; Hu, Z.; Fu, Y.; Yang, K.; Wang, R.; Shi, G.; Feng, Z.; Yang, Q.; Yu, L. Underground Morphological Detection of Ground Fissures in Collapsible Loess Area Based on Three-Dimensional Laser Scanning Technology. Remote Sens. 2022, 14, 424. https://doi.org/ $10.3390 /$ rs 14020424

Academic Editor: Riccardo Roncella

Received: 29 December 2021

Accepted: 13 January 2022

Published: 17 January 2022

Publisher's Note: MDPI stays neutral with regard to jurisdictional claims in published maps and institutional affiliations.

Copyright: (c) 2022 by the authors. Licensee MDPI, Basel, Switzerland. This article is an open access article distributed under the terms and conditions of the Creative Commons Attribution (CC BY) license (https:// creativecommons.org/licenses/by/ $4.0 /)$.

\begin{abstract}
Underground coal mining inevitably causes ground fissures, especially permanent cracks that cannot be closed at the boundary of the working face. Studying the underground threedimensional morphology of the permanent cracks allows one to accurately constrain the formation and development of the ground fissures. This information will contribute to reducing mine disasters and is also a prerequisites to avoid environmental pollution. We selected the Zhangjiamao coal mine (China), which is situated in a collapsible loess area, as a case study for deciphering the formation of permanent cracks. After injecting gypsum slurry into the mine, a three-dimensional model of the ground fissures is obtained by three-dimensional (3D) laser scanner technology that records the $3 \mathrm{D}$ underground morphology. Integrating the geological context of a collapsible loess area, the characteristics and main processes of the ground fissure development are constrained: (1) The width of the ground fissure decreases to 0 with increasing depth and is strongly affected by the soil composition. (2) Along the vertical extension direction, the ground fissures are generally inclined to the inner-side of the working face, but the direction remains uncertain at different depths. (3) The transverse propagation direction of the ground fissure becomes more complex with increasing depth. (4) Under the influence of soil texture and water, loose soil fills the bottom of the ground fissure, thus affecting the underground 3D morphology.
\end{abstract}

Keywords: three-dimensional laser scanning technology; ground fissure; underground three-dimensional morphology; collapsible loess area

\section{Introduction}

Coal is currently still the main energy source in China [1]. According to BP's Statistical Review of World Energy 2020, the world's coal mining volume was 7.742 billion tons. China's coal mining volume of 3.902 billion tons accounts for ca. 50\% of the world's volume. In China's energy structure, coal resources still account for 57\% [2]. Due to the geology of the coal seam storage in China, the coal is mainly exploited by underground mining [3]. Underground mining transfers the movement and deformation of the rock strata to the surface, which may cause surface collapse and substantial damage of the environment and infrastructure [4,5]. Ground fissures are widely distributed among the surface damage, causing many, often long-lasting, problems and disasters [6]. This may cause the reduction of the soil quality and the contamination of water resources and may also weaken the structures and stability of buildings [7-13]. Ground steps and ground 
fissures caused several damages to building objects, small architecture elements, and roads in surrounding area in the greatest Polish hard coal deposit (Upper Silesian Basin), including a old Catholic Church [14]. Mining activity in a lignite mine near Mavropigi (northern Greece) induced ground fissures that caused the sustained damages of many houses in the village and necessitated the relocation of the village [15]. Ground fissures significantly reduce the shoot and root biomass and the contents of N, P, and K in plants, lower the chlorophyll content and the leaf area, and alter the hormone balance in roots, thus reducing GA, IAA, and CTK levels and increasing the ABA level [16]. Moreover, ground fissures also reduce the soil moisture content [17]. In semi-arid, aeolian sand areas, comparable to the unexploited zone and the uncracked zone, each layer of $10 \sim 90 \mathrm{~cm}$ in the ground fissures area has a significant impact on the soil water content, which varies with depth [18]. Due to erosion induced by heavy rain, the ground fissures in collapsible loess areas will form scouring ditches, which expand the damage scope of the surface and reinforce the extent of the damage to surface. Beaded holes of different sizes may form under the topsoil and may induce sudden and random damages [19]. Therefore, governing the distribution characteristics and underground development morphology of ground fissures is a primary task to reduce the damage of land resources, infrastructure, and the ecological environment [5].

Several technical methods are currently applied to identify ground fissures, including field survey [20], radar detection technology [13,21,22], satellite remote sensing technology [23-26], and UAV [23,25-27]. The precision of UAV can attain the centimeter level [28]. After the identification of ground fissures, the surface morphology of fissures can be refined. The width and length on the surface are easily obtained. The commonly used methods include steel ruler measurements and image interpretations. However, it is difficult to observe the underground three-dimensional morphological characteristics of ground fissures, such as width, depth, and extension direction. Therefore, subsurface morphology is the focus of current ground fissures research [29]. The detection methods for the 3D analysis of ground fissures mainly include the steel ruler measurement method [30], ground penetrating radar method [31], ultrasonic method [32,33], plastic rod measurement method [34], and on-site excavation method [35]. The principles, advantages, and disadvantages of the detection methods are summarized in Table 1.

Table 1. The principles, advantages and disadvantages of various detection methods.

\begin{tabular}{|c|c|c|c|}
\hline Detection Method & Principle & Advantage & Disadvantage \\
\hline $\begin{array}{l}\text { Steel ruler } \\
\text { measurement } \\
\text { method }\end{array}$ & $\begin{array}{l}\text { The steel ruler is vertically inserted into the bottom } \\
\text { of the ground fissure. The depth is obtained by } \\
\text { reading the steel ruler }[30,36] \text {. }\end{array}$ & $\begin{array}{l}\text { Suitable for } \\
\text { shallow ground } \\
\text { fissures. Easy } \\
\text { to operate. }\end{array}$ & $\begin{array}{l}\text { The application is limited and } \\
\text { largely affected by the } \\
\text { morphology of the ground } \\
\text { fissures and the density of the } \\
\text { sampling points. In general, the } \\
\text { measured value is slightly lower } \\
\text { than the real value }\end{array}$ \\
\hline $\begin{array}{l}\text { Ground } \\
\text { penetrating radar } \\
\text { method }\end{array}$ & $\begin{array}{l}\text { Transmission of high-frequency electromagnetic } \\
\text { waves underground using the launch antenna. The } \\
\text { electromagnetic wave will be reflected as it passes } \\
\text { through the contact surface of different electrical } \\
\text { properties. The receiving antenna obtains the } \\
\text { reflected electromagnetic wave. In combination } \\
\text { with the morphology, amplitude, and dynamic } \\
\text { characteristics of the reflected electromagnetic } \\
\text { wave, it is possible to model the composition, } \\
\text { morphology, depth, and spatial orientation of the } \\
\text { under-ground dielectric layer }[14,31,37] \text {. }\end{array}$ & $\begin{array}{l}\text { The results are } \\
\text { two-dimensional } \\
\text { images. }\end{array}$ & $\begin{array}{l}\text { The accuracy is closely related } \\
\text { to the performance of the } \\
\text { antenna. The 3D morphology of } \\
\text { the ground fissures is } \\
\text { not resolved. }\end{array}$ \\
\hline
\end{tabular}


Table 1. Cont.

\begin{tabular}{|c|c|c|c|}
\hline Detection Method & Principle & Advantage & Disadvantage \\
\hline Ultrasonic method & $\begin{array}{l}\text { As the transmitted ultrasonic waves encounter } \\
\text { cracks during their propagation, they produce } \\
\text { physical phenomena, such as reflection, refraction, } \\
\text { and diffraction, which will prolong the } \\
\text { propagation time. The depth is modeled by the } \\
\text { change of time. Single-plane detection is } \\
\text { applicable only in the case of one measurable } \\
\text { surface at the location of the ground fissures. The } \\
\text { depth is inferred from the different propagation } \\
\text { paths of the span and the non-span ultrasonic } \\
\text { wave in the same range }[32,33,38] \text {. }\end{array}$ & $\begin{array}{l}\text { Suitable for } \\
\text { shallow ground } \\
\text { fissures and easy } \\
\text { to operate. }\end{array}$ & $\begin{array}{l}\text { The echo signal of spherical } \\
\text { defects is usually weak, or the } \\
\text { propagation time change } \\
\text { is equivocal. }\end{array}$ \\
\hline $\begin{array}{l}\text { Plastic rod } \\
\text { measurement } \\
\text { method }\end{array}$ & $\begin{array}{l}\text { Very robust thin elastic plastic rod (about } 1 \mathrm{~mm} \text { in } \\
\text { diameter) with a ruler. The rod is inserted into the } \\
\text { ground fissure until it reaches the hard surface. } \\
\text { The length of the plastic rod is regarded as the } \\
\text { approximate value of the development depth of } \\
\text { the ground fissures [39]. }\end{array}$ & $\begin{array}{l}\text { Suitable for } \\
\text { shallow ground } \\
\text { fissures and easy } \\
\text { to operate. }\end{array}$ & $\begin{array}{l}\text { Only considers the } \\
\text { development of ground fissures } \\
\text { along the vertical direction. } \\
\text { Does not consider the bending } \\
\text { degree and the crack bifurcation } \\
\text { phenomenon. Therefore, the } \\
\text { precision is rather poor, and the } \\
\text { measured value is generally } \\
\text { lower than the actual depth. } \\
\text { Moreover, the measurement is } \\
\text { time-consuming and laborious. }\end{array}$ \\
\hline $\begin{array}{c}\text { On-site excavation } \\
\text { method }\end{array}$ & $\begin{array}{l}\text { Conventional method to determine the depth of } \\
\text { ground fissures by excavating soil profiles. } \\
\text { Ground fissures are artificially grouted with white } \\
\text { lime. After the soil profile is formed, the depth of } \\
\text { the ground fissure is measured with a steel ruler or } \\
\text { meter ruler. A digital camera can be used to } \\
\text { document a ground fissure image, and the depth is } \\
\text { obtained after processing [40]. }\end{array}$ & $\begin{array}{l}\text { As it can obtain a } \\
\text { complete ground } \\
\text { fissure model, it is } \\
\text { more accurate than } \\
\text { the steel ruler } \\
\text { measurement } \\
\text { method. }\end{array}$ & $\begin{array}{l}\text { The experimental process is } \\
\text { time-consuming and laborious. } \\
\text { The precision is rather poor, and } \\
\text { the soil will be disturbed. }\end{array}$ \\
\hline
\end{tabular}

All listed methods are limited to constrain the underground morphology of ground fissures and are unsuitable to determine the entire three-dimensional underground morphology of ground fissures with the required high precision. Three-dimensional (3D) laser scanning technology is another technological improvement after the implementation of GPS technology [41,42], which can determine the 3D coordinates of the target through contactless scanning, thus creating a 3D model [43]. It is currently mainly used in cultural relic protection [44], forest parameters [45], scene reconstruction [46], and deformation monitoring [47]. In the present study, the 3D laser scanning techniques is used to obtain the underground morphology of the ground cracks induced by underground mining activity in the Zhangjiamao coal mine (China).

The article is structured as follows: In the section "Materials and Methods", we describe the sample material, the experimental set-up, and the data acquisition that ultimately leads to the constructing of a 3D model of the ground fissure. In the section "Results" we present the acquired data and analyze the characteristics of the underground morphology of the fissures, including the width, depth, width-depth ratio, extension angle, and drop of the ground fissure in the transverse and longitudinal sections, respectively. In the section "Discussion" we introduce the complexity of the underground morphology of the ground fissure, the rationality of our experimental results, and the deficiencies of the experimental methods, along with suggestions for improvement. In the section "Conclusions" we summarize the main finding of our study and propose possible objects of future work. The data flow chart is shown in Figure 1. 


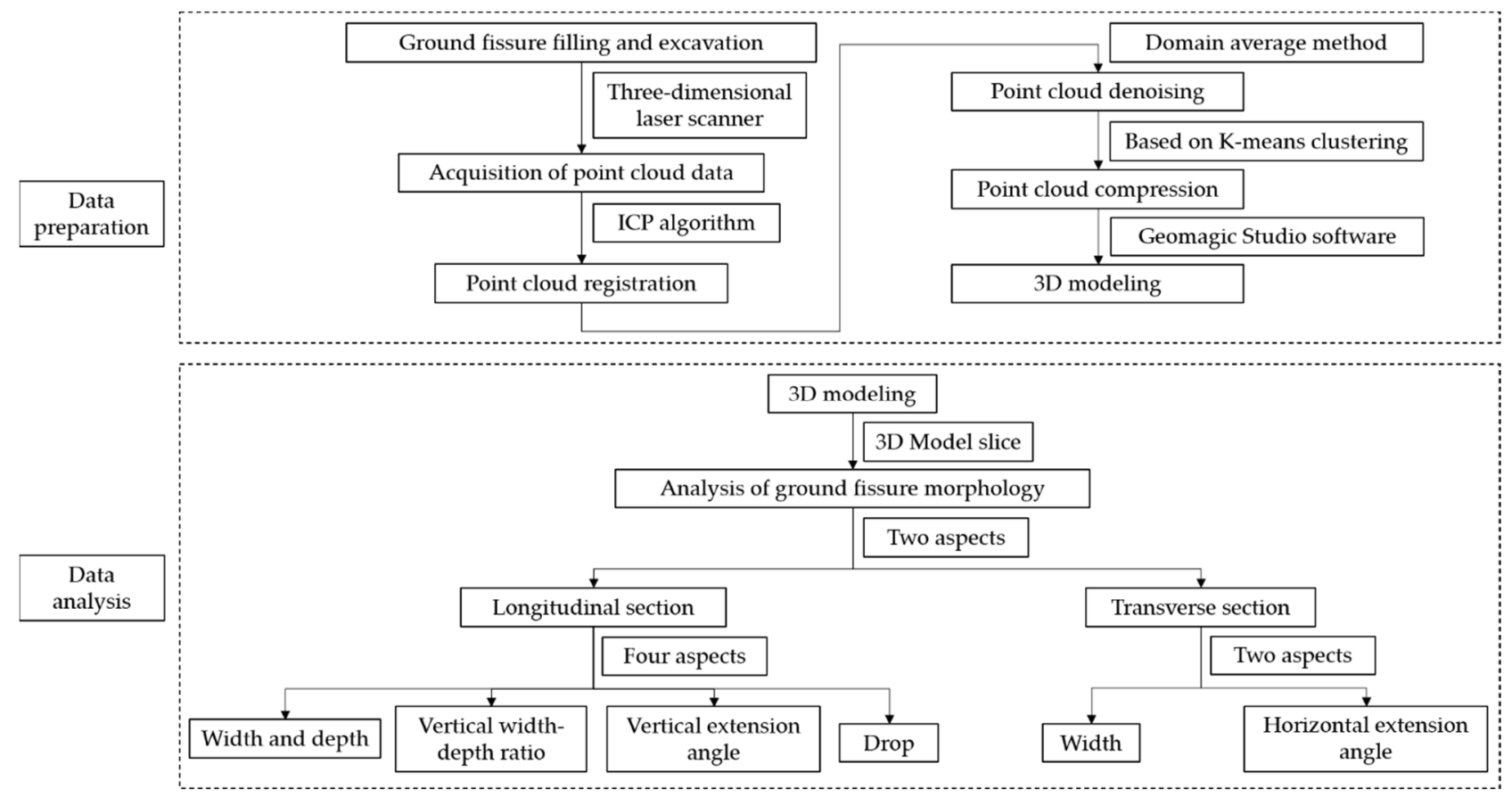

Figure 1. The data flow chart.

\section{Materials and Methods}

\subsection{Location of Study Area}

The study area is the 15211 working face in the Zhangjiamao coal mine (China), which is situated in an area of collapsible loess. According to borehole exposure and data from geological mapping, the strata comprise (from bottom to top): the Middle to Upper Triassic Yanchang Formation (T2-3y), followed by the Middle Jurassic Yan'an Formation (J2y), the Neogene Pliocene Baode Formation (N2b), the Quaternary Middle Pleistocene Lishi Formation (Q21), and Quaternary Holocene Aeolian sand (Q4eol). Quaternary loess with an average thickness of $23.27 \mathrm{~m}$ is grayish brown or dark grayish brown. Loess is sparse and porous, with small capacity and low nitrogen content, but high phosphorus and potassium contents. Zinc and manganese are absent. The $\mathrm{pH}$ value is 8 to 8.5 , and the fertilizer retention ability is weak.

The overall structural type of the working face is monoclinic, with N-S strike and dip to the northwest. The designed mining coal thickness is $5.89 \sim 6 \mathrm{~m}$, the cut length is $296.75 \mathrm{~m}$, and the push mining distance is $2065.72 \mathrm{~m}$. There are no old kilns or abandoned shafts around or overlying the working face. On the surface that represents the working face, there are no farms, households, high-voltage power lines, roads, or other structures.

Based on data analysis and field investigation, permanent cracks located at the boundary of the working face were selected for the present study. Position relationships between the ground fissure and the working face are shown in Figure 2. The picture on the right is an enlargement (by 10 times) of the crack. Figure 2 shows that the ground fissure is located near the glue transportation groove in the 15211 working face, $664.03 \mathrm{~m}$ away from the open cut. The ground fissure extends along the direction of the glue transportation groove in the 15211 working face.

Considering the costs of the filling materials, the limited site conditions, and the difficulty of excavation, the widest part of the ground fissure was selected, with a length of about $3.8 \mathrm{~m}$ and a depth of about $2 \mathrm{~m}$. 


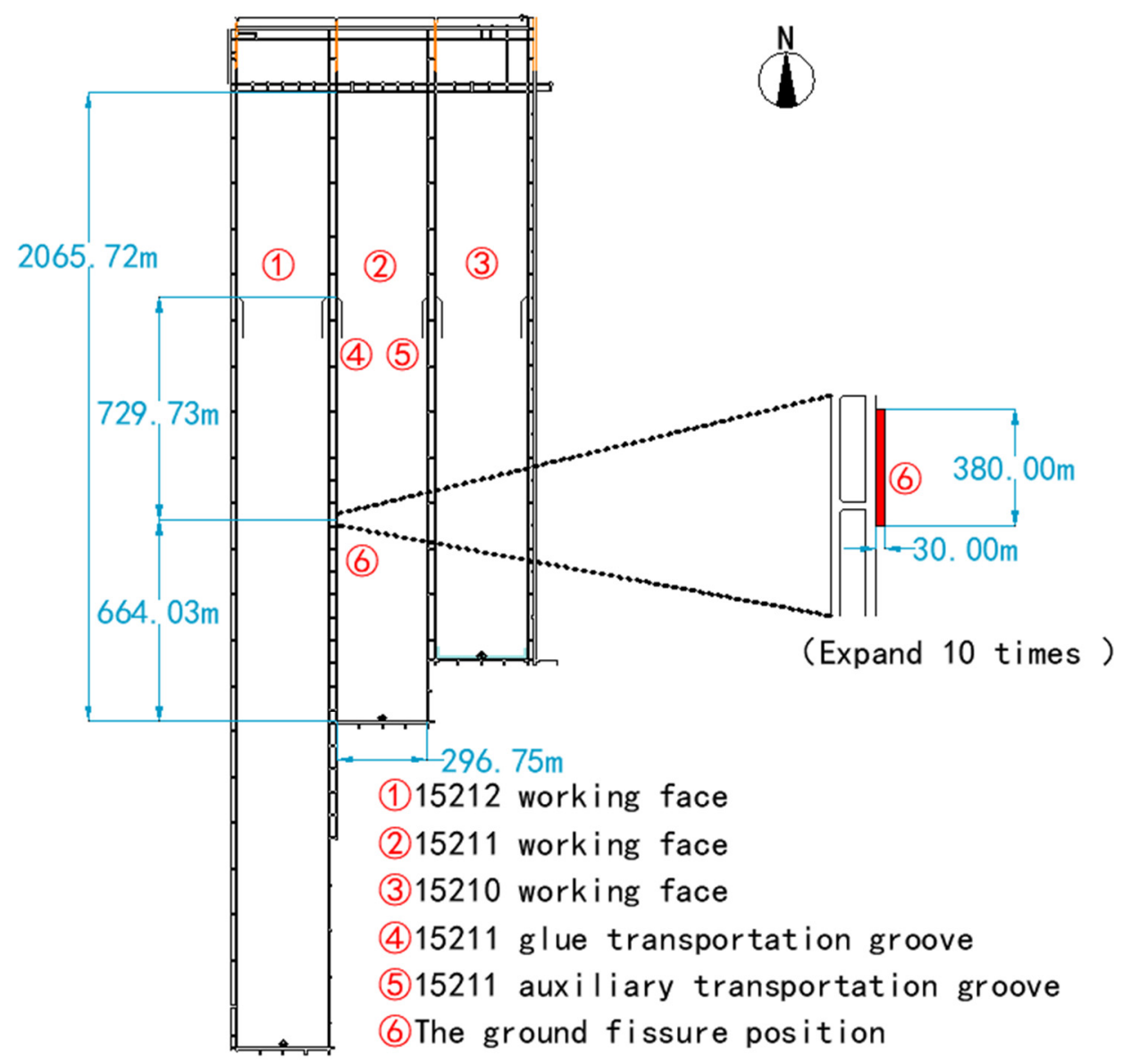

Figure 2. Position relationship between the ground fissure and the working face.

\subsection{Ground Fissure Filling Method and Observation}

\subsubsection{Ground Fissure Filling and Excavation}

At first, both ends of the ground fissure are blocked to ensure the entire length of the studied ground fissure and to prevent unnecessary consumption of gypsum. Subsequently, the ground fissure is filled by gypsum. Mixtures with mass ratios between standard building gypsum powder (GB97761988) and water of 1:1 and 3:2 are used, and the time of initial setting and the final setting time of the two mixtures are considered. A mixture with a 1:1 ratio is used to fill the bottom part of the ground fissure in the initial period of the measurement. The 3:2 mixture is more viscous and is used to fill the upper part of the ground fissure during the later stage of the measurement [48]. During the filling process, uniform mixing of the two materials ensures the perpetuation of the fluid state of the slurries, which prevent the formation of lumpy textures. The filling height is flush with both ends of the ground. The gypsum consumption is about $1.7 \mathrm{t}$. The field filling results of the ground fissure are shown in Figure 3. The left picture shows the image obtained by UAV. DJI M210 RTK V2 is selected as the flight platform and is equipped with a Zenmuse XT2 sensor with a $19 \mathrm{~mm}$ lens. The aerial height is set at $50 \mathrm{~m}$, and the aerial photograph scale is about 1:2632. The filling length is $3.8 \mathrm{~m}$, and the width ranges between $2.1 \sim 3.3 \mathrm{~m}$.

After solidification of the gypsum slurry, the ground fissure excavation is carried out. During this process, it is important not to damage the paste. The further steps are as follows:

First, the surface of the ground fissure that faces the outside of the working face (i.e., the west side) is excavated. The soil on the paste surface has to be carefully cleaned. The red border in Figure 4 a shows the western part of the ground fissure paste. After point cloud data acquisition, the soil is backfilled and compacted. 


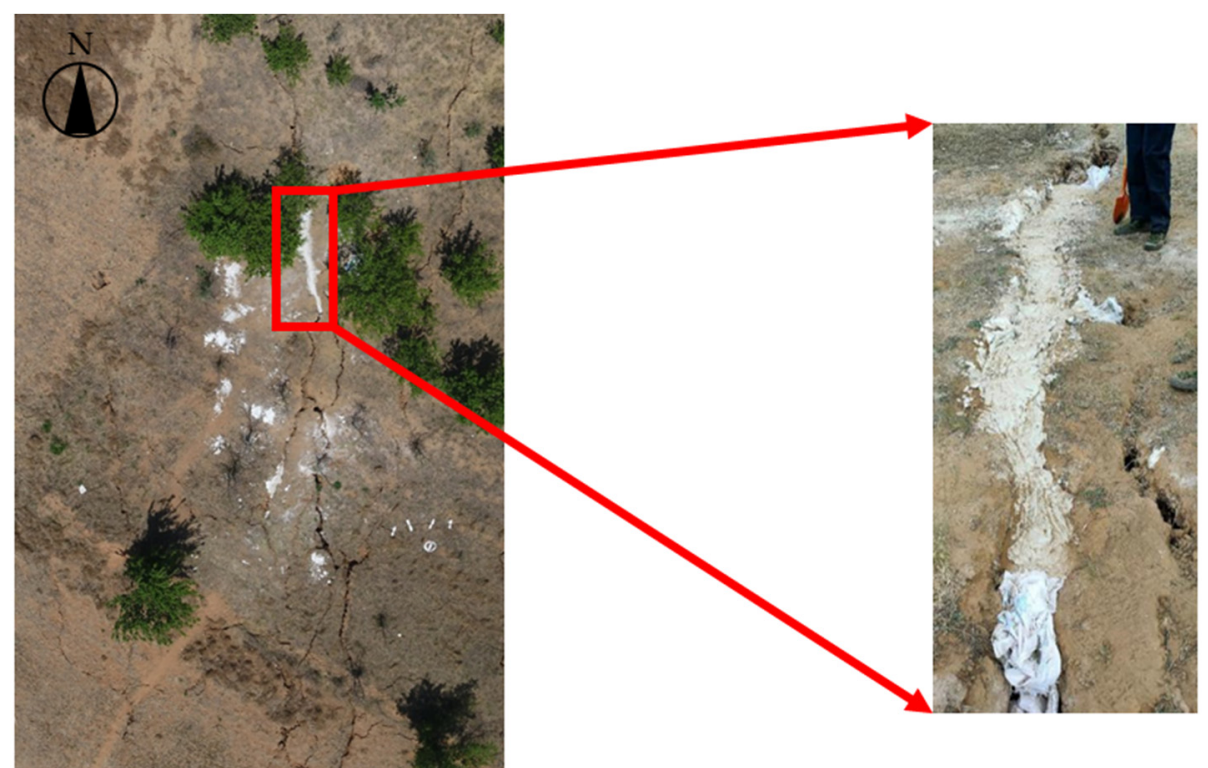

Figure 3. Field filling results of the ground fissure.

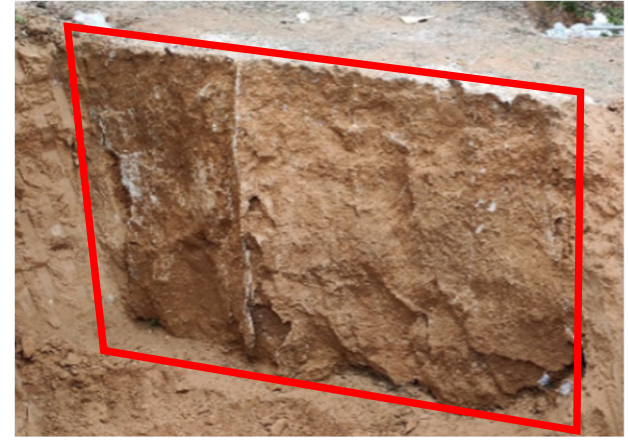

(a)

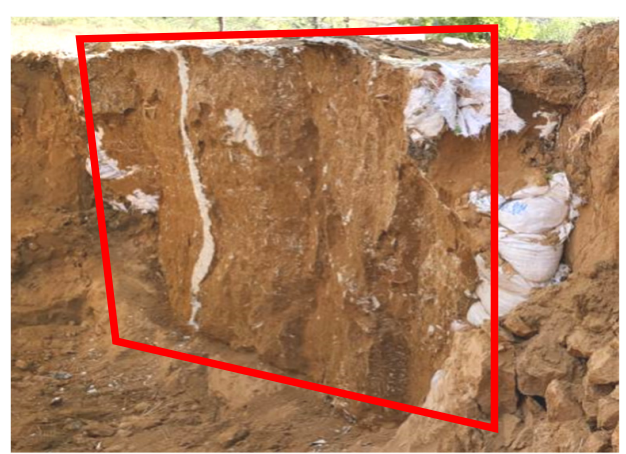

(b)

Figure 4. Excavation results of the ground fissure: (a) Excavation results in the western part of the ground fissure; (b) Excavation results in the eastern part of the ground fissure.

Subsequently, the surface of the ground fissure that faces the inside of the working face (i.e., the east side) is excavated, and the above-described steps are repeated The red border in Figure $4 \mathrm{~b}$ is the eastern part of the ground fissure paste.

After completion of this procedure, it is necessary to consider the leveling of the land and to minimize the damage of the excavation to the land resources.

\subsubsection{Data Acquisition Method}

\section{Instrument Selection}

We used the RIEGL VZ-1000 three-dimensional laser scanning system, with a precision of $5 \mathrm{~mm} / 100 \mathrm{~m}$. The supporting camera is a Nikon D600 with an effective pixel density of 24.26 million, and reflectors.

\section{Design of Data Acquisition Scheme}

Due to the need to scan the east and west sides of the ground fissure, we use reflectors to ensure the precision of point cloud registration. In this process, information from at least three reflectors is acquired at the same location in two stations. The reflectors are pasted on thick tree trunks, and the lower positions are chosen as far as possible to reduce the influence of the tiny movement of the reflectors caused by the wind. A total of 10 reflectors are arranged in the study area. Their positions are shown in Figure 5. 


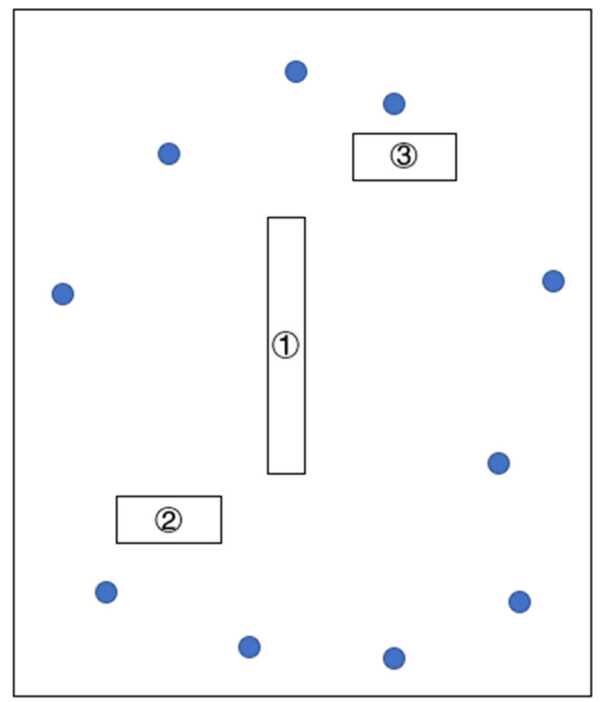

(1) Ground fissure location
(2)The first station
(3)The second station
Reflector

Figure 5. Position of reflectors.

\section{Acquisition of Point Cloud Data}

During data acquisition, the scanning distance is set to about $5 \mathrm{~m}$, and the scanning interval is set to $0.002 \mathrm{~m}$. Figure 6 shows field data collected in the western part of the ground fissure, and Figure 7 shoes the original point cloud data in the western part of the ground fissure. The white part in the red frame of the two figures is gypsum, representing the ground position of the ground fissure. The green part in Figure 7 is the surface vegetation.

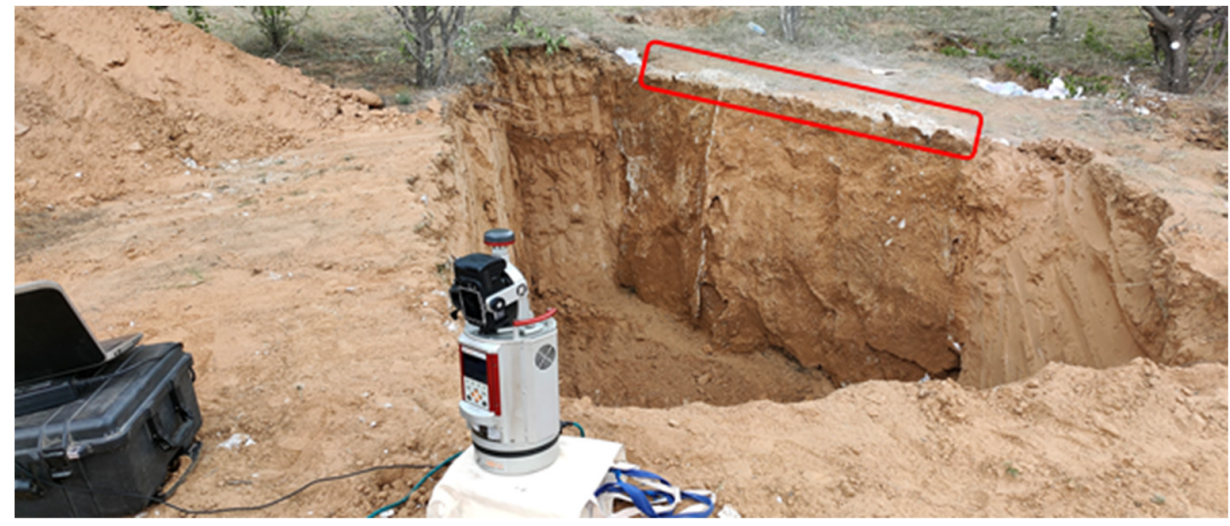

Figure 6. Field data collection in the western part of the ground fissure.

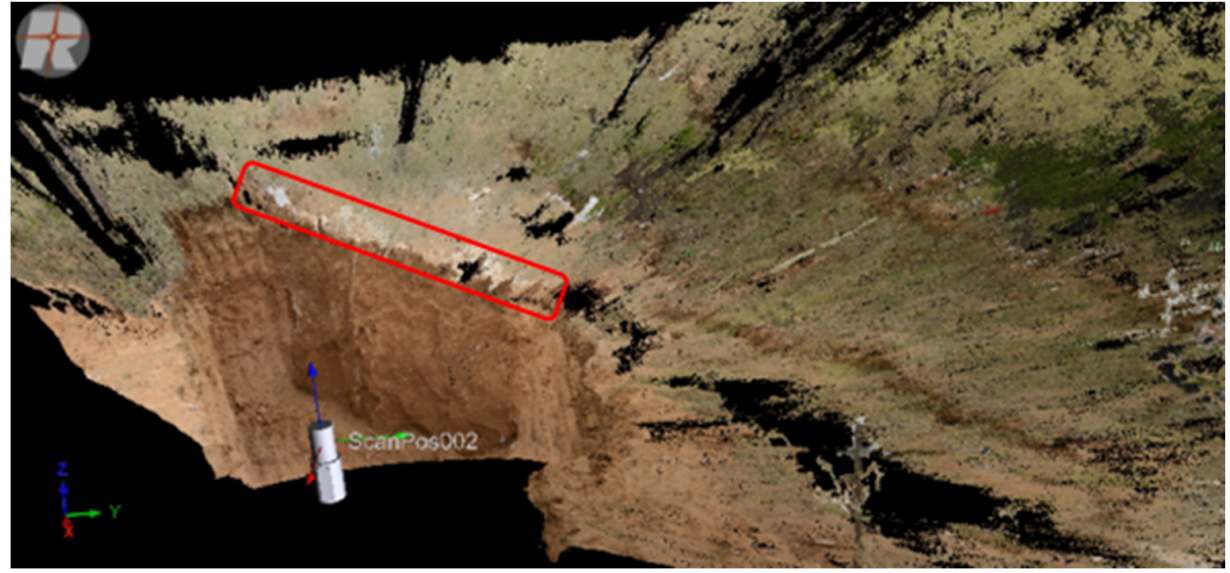

Figure 7. The original point cloud data in the western part of the ground fissure. 


\subsection{Data Processing Results}

Data preprocessing includes point cloud registration, point cloud denoising, point cloud compression, and 3D modeling. Considering the boundary effect, a part at both ends of the ground fissure is removed to obtain a length of $2.5 \mathrm{~m}$. The result is shown in Figure 8. Data preprocessing follows a successive scheme:

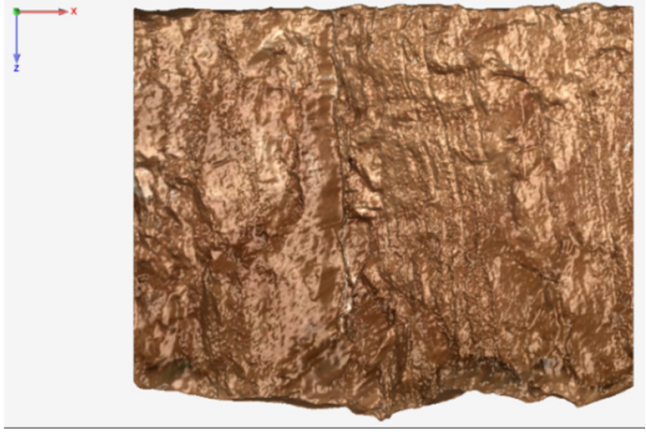

(a)

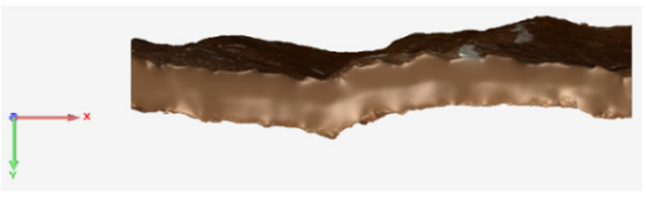

(c)

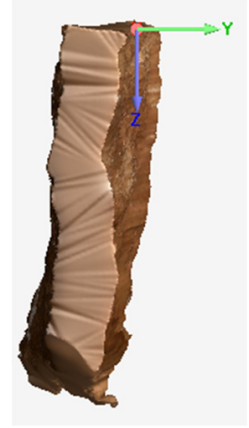

(b)

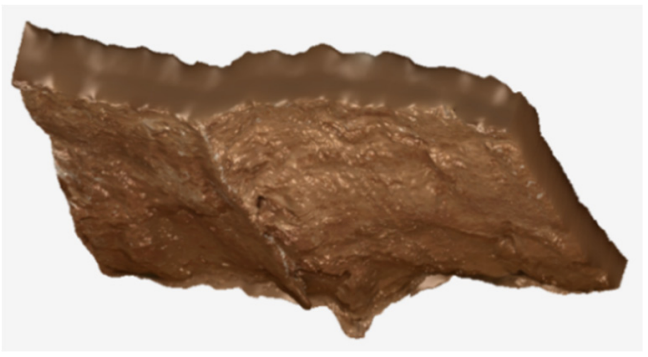

(d)

Figure 8. 3D modeling of the ground fissure: (a) Front view of the ground fissure; (b) Left view of the ground fissure; (c) Top view of the ground fissure; (d) 45-degree side view of the ground fissure.

1. Point cloud registration

Point cloud registration includes coarse and fine registration. According to the reflectors in the 3D point cloud data of the two stations, the rough registration is completed using RISCAN PRO software. The ICP algorithm is used for the fine registration [49].

\section{Point cloud denoising}

The implementation of noise points is inevitable during data acquisition. We selected the domain average method for denoising [43].

\section{Point cloud compression}

Massive point cloud data is meaningless to describe the shape of the object but will slow down the speed of data processing. We performed data compression based on $\mathrm{K}$-means clustering [50].

4. 3D modeling

3D modeling uses an algorithm to generate polygons from the chaotic 3D point cloud data, and finally restores the shape of the studied object. This process was carried out with Geomagic Studio 2013 software.

\subsection{Description of the Ground Fissures}

The description of the ground fissure morphology mainly includes the following parameters: 
1. Width: The surface width of the ground fissure represents the extent of the development of the ground fissure along the horizontal direction. The value reflects the damage degree of the ground fissure to surface continuity.

2. Depth: The vertical depth of the ground fissure represents the extent of the development of the ground fissure along the vertical direction. The value reflects the influence of the ground fissure on surface water and mechanical properties.

3. Width-depth ratio: The ratio of the ground fissure width (in $\mathrm{cm}$ ) to the depth (in $\mathrm{cm}$ ) is related to the change of the ground fissure width with increasing depth.

4. Extension angle: The angle between the ground fissure and the standard direction reflects the degree of the offset of the ground fissure.

5. Drop: The height of the ground fissure step.

\section{Results}

\subsection{Model Slice}

Using Geomagic Studio 2013 software, the ground fissure is cut along the horizontal and vertical directions at $10 \mathrm{~cm}$ intervals to obtain 25 longitudinal sections and 19 transverse sections. The longitudinal sections are numbered $\mathrm{V}-1-\mathrm{V}-25$, and the transverse sections $\mathrm{H}-0-\mathrm{H}-18$. The cutting result is shown in Figure 9. Figures 10 and 11 show the ground fissure morphology of $\mathrm{V}-2$ and $\mathrm{H}-6$, respectively.

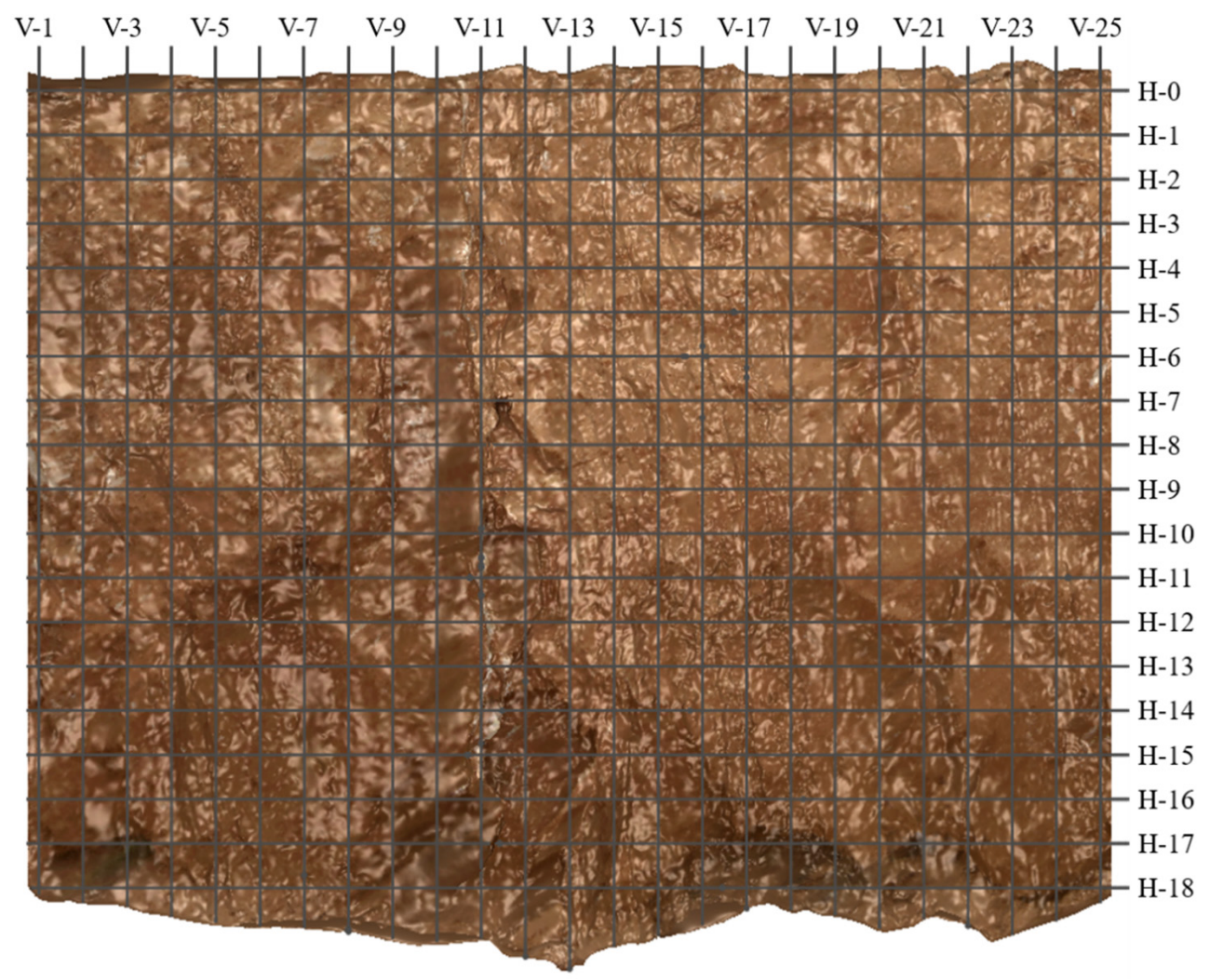

Figure 9. The cutting result.

We divided the ground fissure morphology into two aspects: A longitudinal section and a transverse section. Once the depth of the ground fissure exceeds $180 \mathrm{~cm}$, the width suddenly drops to 0 (Figure 10), which is related to the influence of the collapsible loess, a rather random process [31,34]. Therefore, we concentrate our investigation on the ground fissure morphology between depths of $0 \sim 180 \mathrm{~cm}$. 


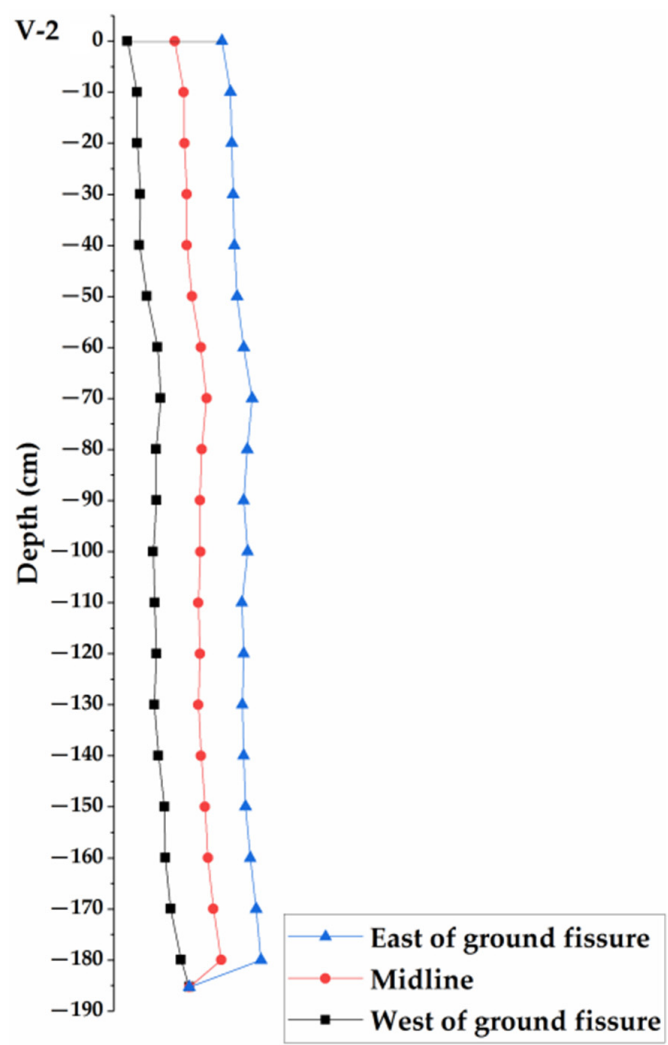

Figure 10. The ground fissure morphology of V-2.
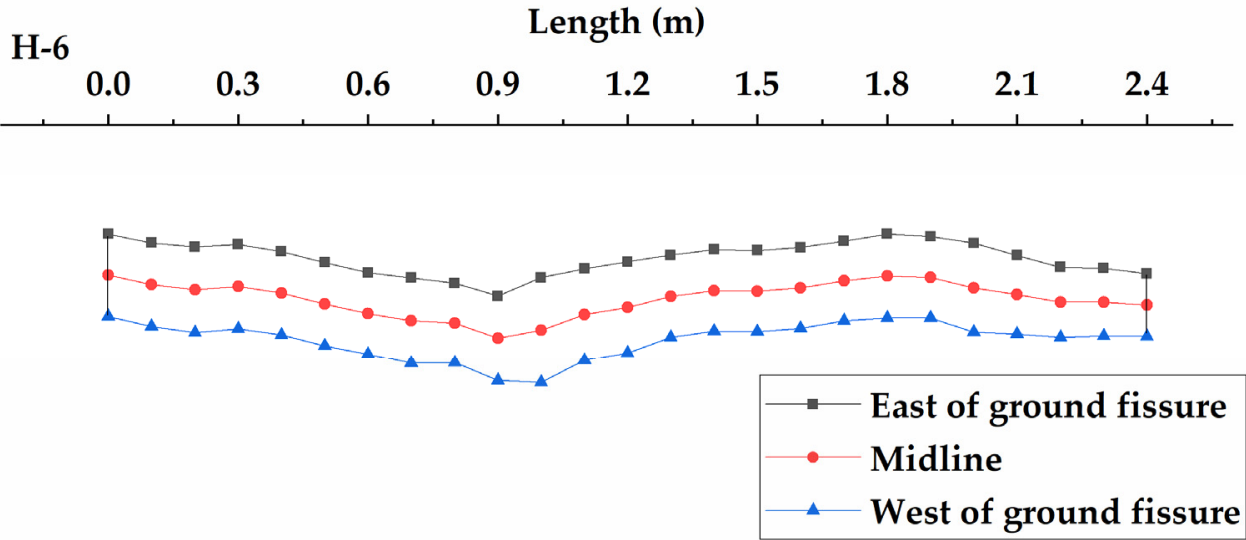

Figure 11. The ground fissure morphology of H-6.

\subsection{Analysis of Ground Fissure Morphology}

\subsubsection{Longitudinal Section of the Ground Fissure Analysis}

1. Width and Depth of the Ground Fissure

The frequency histogram of the ground fissure width is shown in Figure 12. The width distribution is $0.061 \sim 0.358 \mathrm{~m}$, which basically conforms to the normal distribution [32,36]. Almost $80 \%$ of the values range between $0.20 \sim 0.30 \mathrm{~m}$.

Figure 13 illustrates the variation of the width with depth, and a decrease of the width with increasing depth is evident. However, the variation of depth and width of each longitudinal section varies slightly, and two groups are observed. In the first group, exemplified by V-8, the width slightly increases at some depths, but the overall downward trend remains unaffected. The second group, exemplified by V-12, is characterized by large variation of the width. In the depth range of $100 \sim 120 \mathrm{~cm}$, the width largely increases, but decreases rapidly in the depth range of $120 \sim 150 \mathrm{~cm}$. 


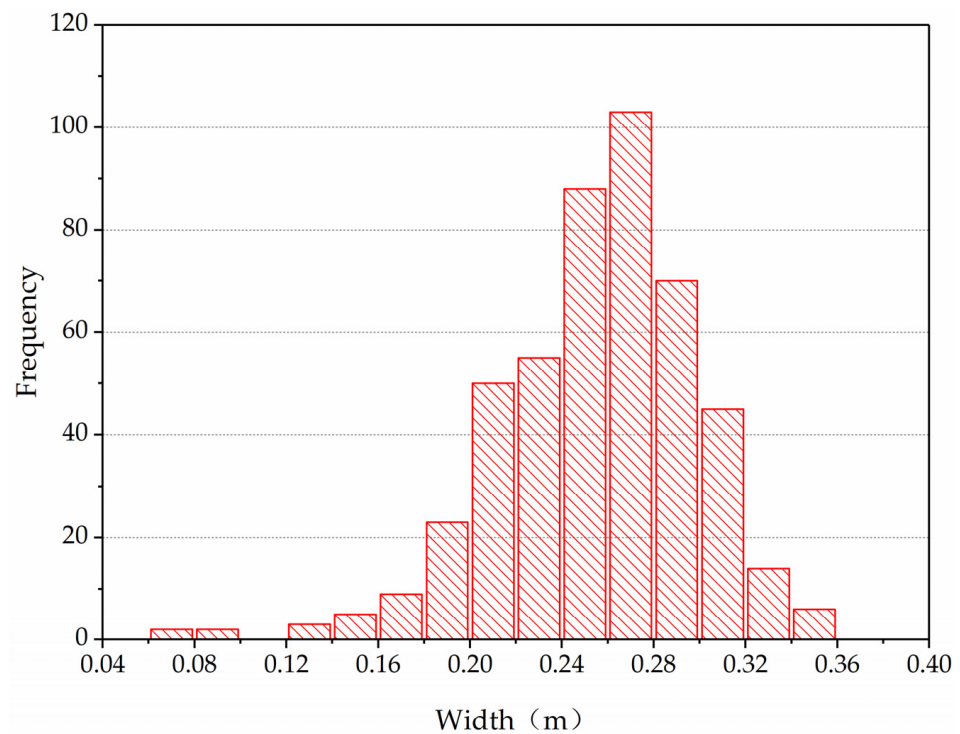

Figure 12. The frequency histogram of the ground fissure width.
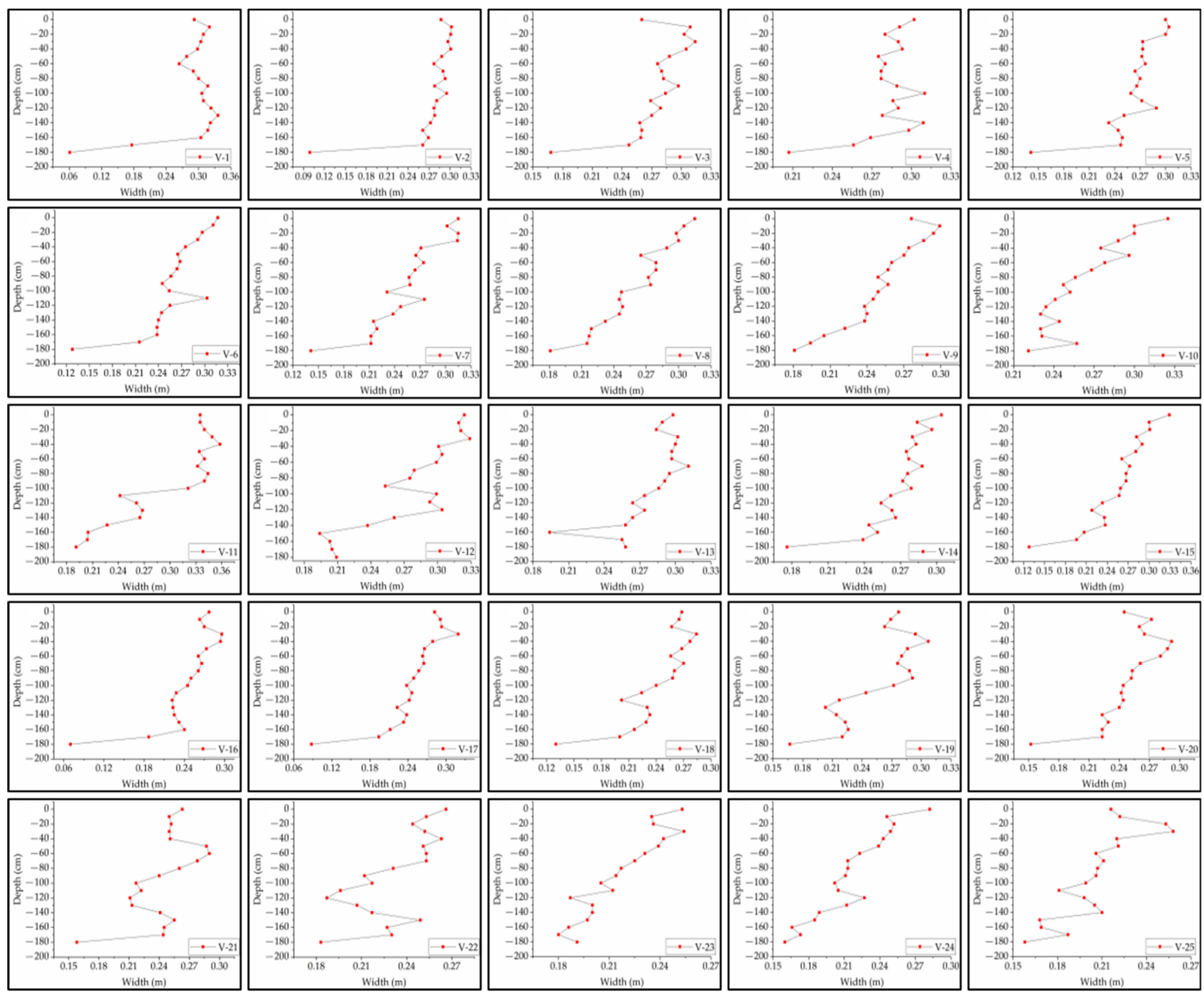

Figure 13. The variation of the width with depth. 


\section{Vertical Width-Depth Ratio of the Ground Fissure}

The relationship between width-depth ratio and depth of the ground fissure is illustrated in Figure 14. The diagram documents that the variation trend of the width-depth ratio of each longitudinal section with the depth is consistent. The change is from fast to slow, ranging from $320 \%$ to $3.39 \%$. The width-depth ratio changes rapidly at a depth of $0 \sim 20 \mathrm{~cm}$ and more slowly between $20 \sim 70 \mathrm{~cm}$, and it becomes progressively flat at depths of $70 \sim 180 \mathrm{~cm}$.

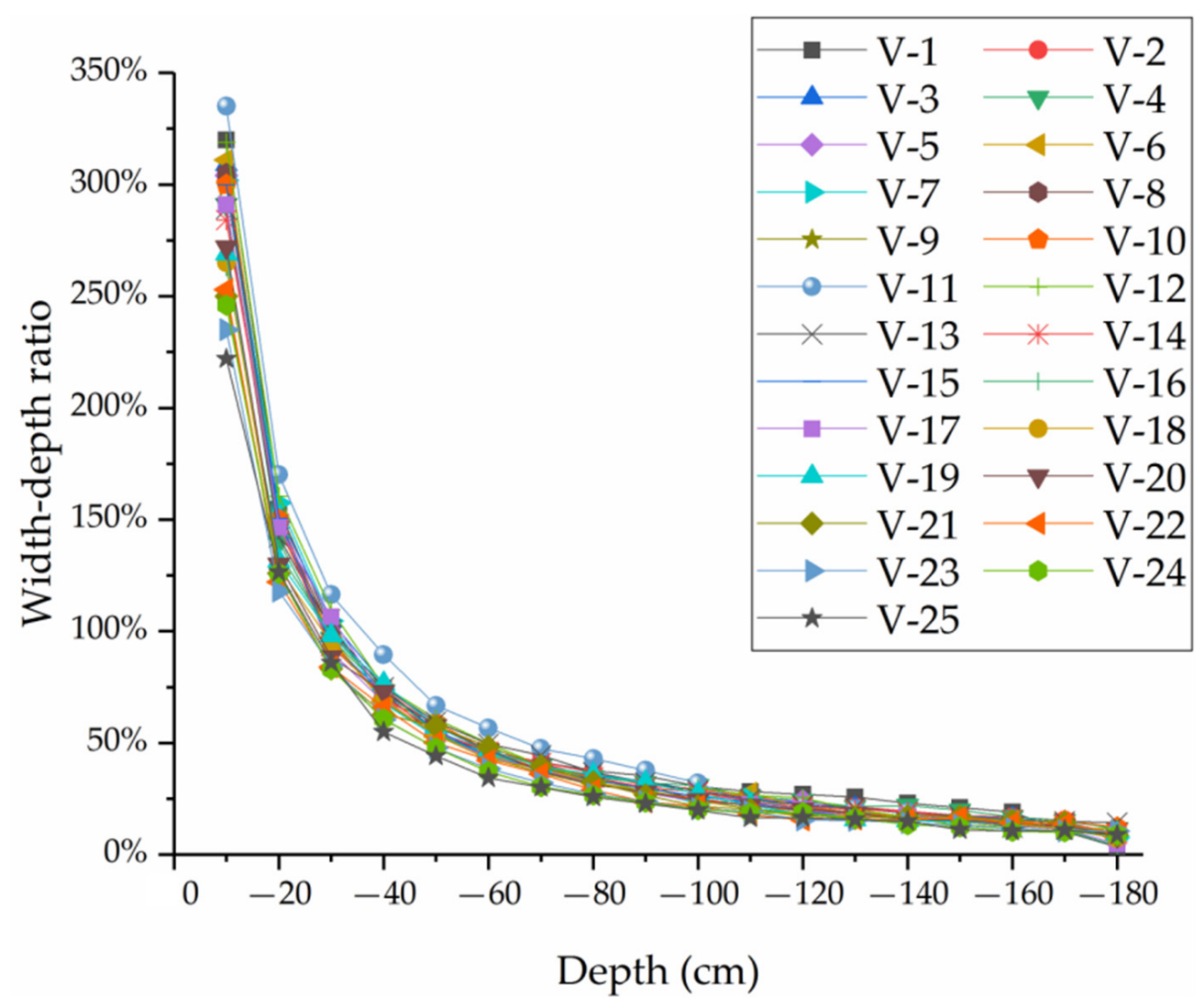

Figure 14. The relationship between width-depth ratio and depth of the ground fissure.

\section{Vertical Extension Angle of the Ground Fissure}

The vertical extension angle of the ground fissure refers to the included angle between the ground fissure and the vertical direction. It is positive at the outside of the working face and negative at the inside of the working face. Two aspects of the angle are considered:

(1) Vertical extension angle of the ground fissure at each depth

The histogram of the vertical extension angle of the ground fissure in each longitudinal section varies with depth and is constructed at an interval of $10 \mathrm{~cm}$ (Figure 15). The variation for the angle ranges between $-18.3^{\circ} \sim 15.5^{\circ}$, showing that the downward extension direction of the ground fissure is inconsistent at different depth levels.

Figure 15 shows that the vertical extension angles of most longitudinal sections are biased towards the inside of the working face. The degree of the bias rises with the depth, and the angle increases slightly. However, some longitudinal sections with large fluctuations in the vertical extension angle remain, such as V-13. The vertical extension angle direction of V-13 is outside-in first, and then inside-out, and finally outside-in of the working face. 


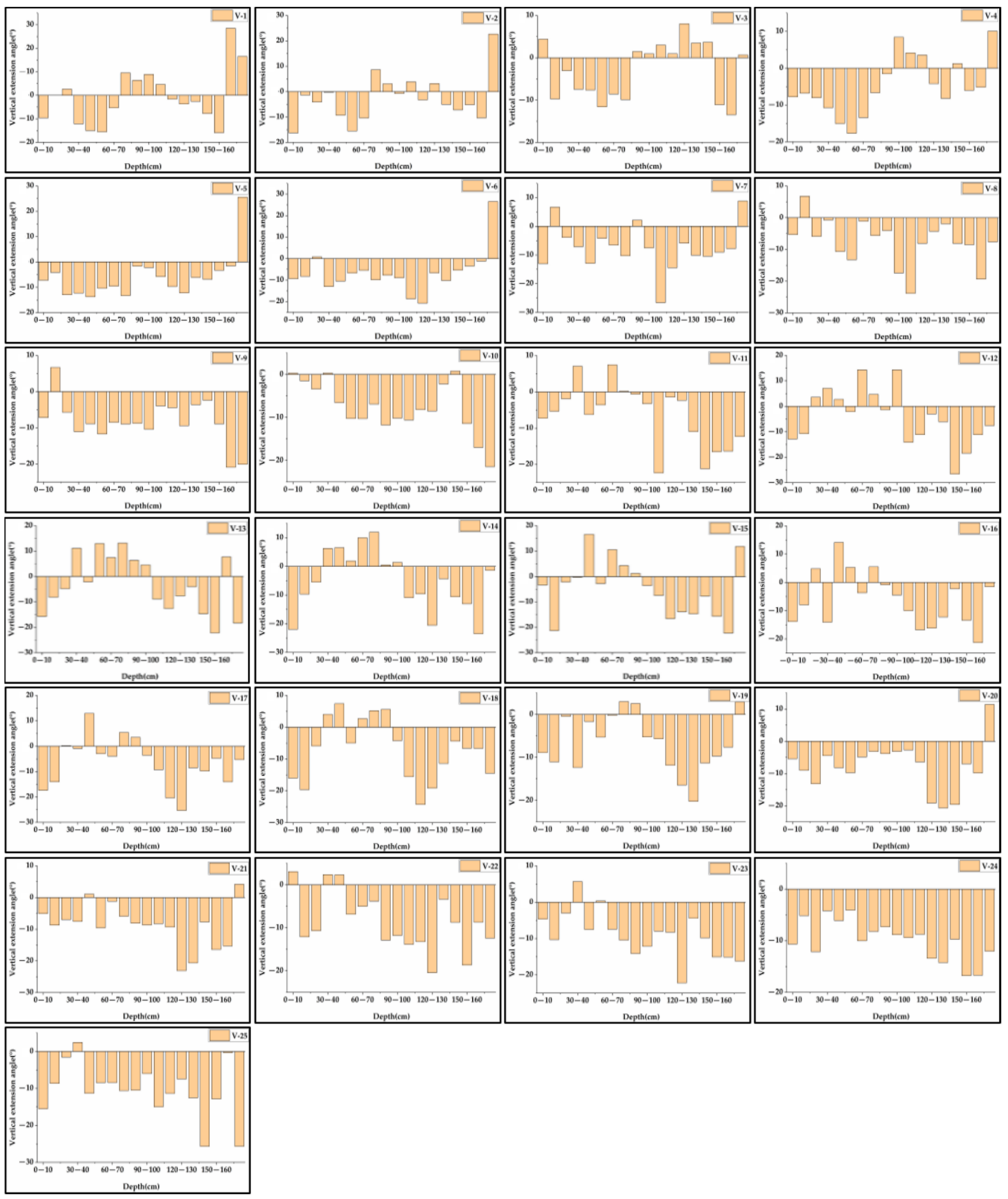

Figure 15. The vertical extension angle of the ground fissure in each longitudinal section varies with depth.

(2) Vertical overall extension angle of the ground fissure

The vertical overall extension angles of V-13 and V-22 are shown in Figure 16. The green line is the vertical overall extension direction. The diagram shows a bias towards the 
inside of the working face for all measurements (i.e., the direction of the blue line in the figure). The angle is in the range of $-11.1 \sim-2.6^{\circ}$.

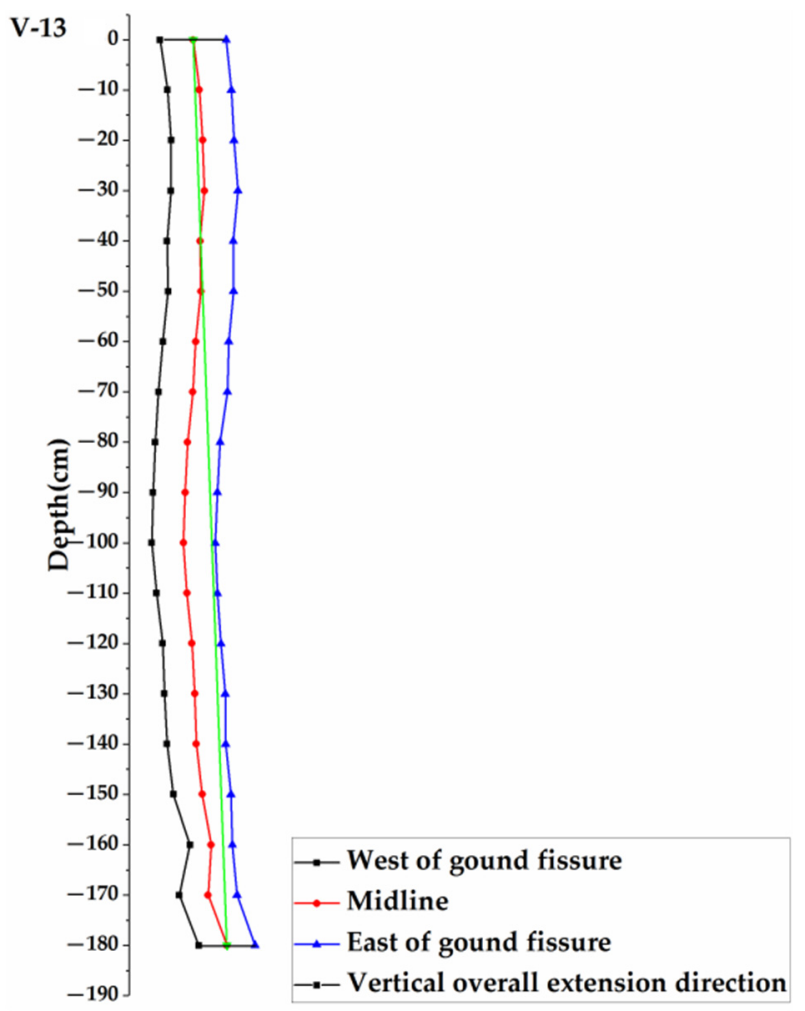

(a)

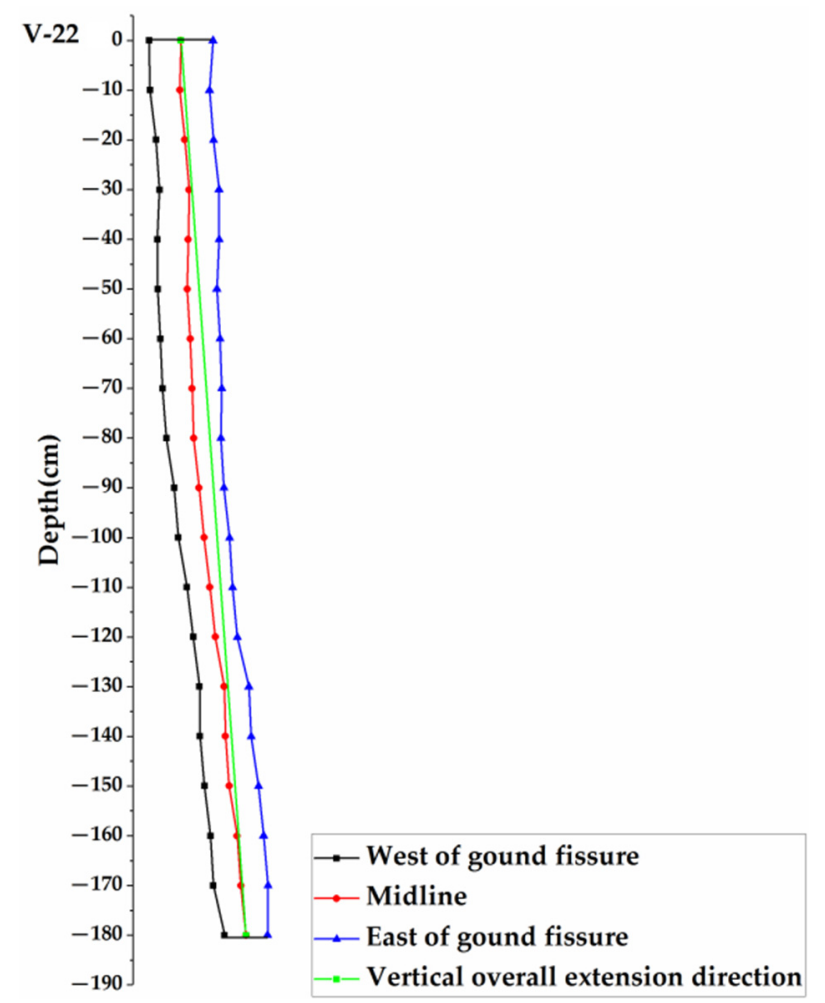

(b)

Figure 16. The vertical overall extension angle of the ground fissure: (a) The vertical overall extension angle of V-13; (b) The vertical overall extension angle of V-22.

\section{Drop of the Ground Fissure}

The ground fissure drop in each longitudinal section is shown in Figure 17. The drop shows a large variation, in the range of $0.3 \sim 56.4 \mathrm{~mm}$, with an average of $18.0 \mathrm{~mm}$. Most values are below $20 \mathrm{~mm}$. A direct relationship between the drop and the position of the longitudinal section is not evident from the data.

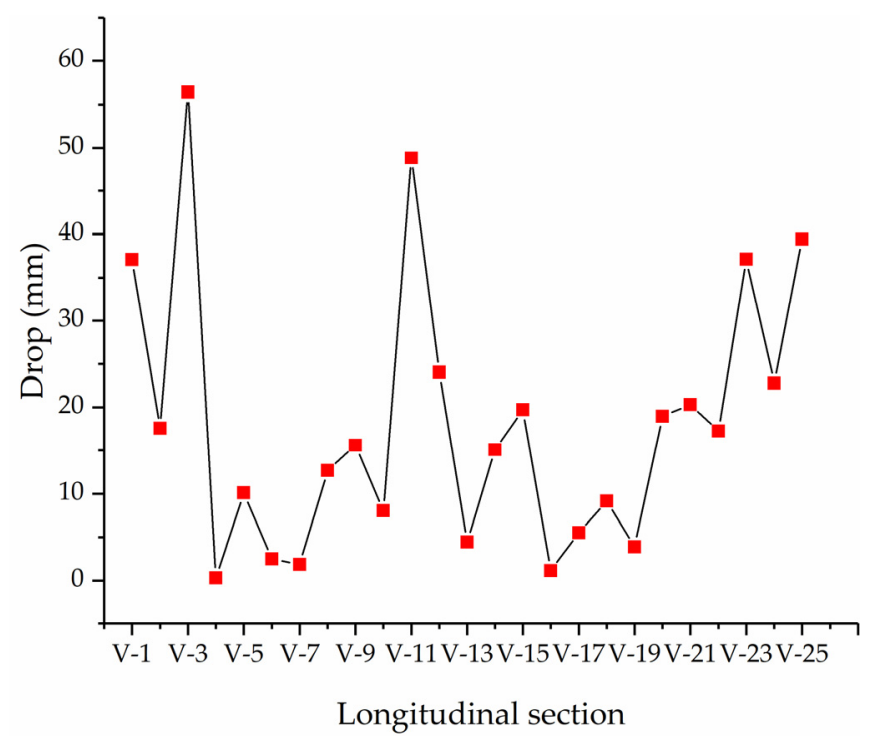

Figure 17. The ground fissure drop in each longitudinal section. 


\subsubsection{Transverse Section of the Ground Fissure Analysis}

\section{Width of the Ground Fissure}

Table 2 shows the characteristic values of the ground fissure width in each transverse section. Analyzing the range value of the ground fissure width of each transverse section indicates that the range value of the $\mathrm{H}-18$ width is the largest $(0.197 \mathrm{~m})$ and that of the $\mathrm{H}-17$ width is the smallest $(0.088 \mathrm{~m})$. Other values are distributed in the range of $0.1 \sim 0.149 \mathrm{~m}$. The width of each cross section generally tends towards a constant value.

Table 2. The characteristic values of the ground fissure width in each transverse section.

\begin{tabular}{ccccc}
\hline Transverse Section & $\begin{array}{c}\text { Maximum } \\
(\mathbf{m})\end{array}$ & $\begin{array}{c}\text { Minimum } \\
(\mathbf{m})\end{array}$ & $\begin{array}{c}\text { Average Value } \\
(\mathbf{m})\end{array}$ & $\begin{array}{c}\text { Range Value } \\
(\mathbf{m})\end{array}$ \\
\hline H-0 & 0.335 & 0.216 & 0.288 & 0.119 \\
H-1 & 0.335 & 0.222 & 0.285 & 0.113 \\
H-2 & 0.340 & 0.236 & 0.285 & 0.104 \\
H-3 & 0.349 & 0.249 & 0.289 & 0.100 \\
H-4 & 0.358 & 0.220 & 0.282 & 0.138 \\
H-5 & 0.334 & 0.221 & 0.275 & 0.113 \\
H-6 & 0.340 & 0.206 & 0.270 & 0.134 \\
H-7 & 0.332 & 0.211 & 0.269 & 0.121 \\
H-8 & 0.344 & 0.207 & 0.265 & 0.137 \\
H-9 & 0.340 & 0.206 & 0.261 & 0.134 \\
H-10 & 0.321 & 0.199 & 0.256 & 0.122 \\
H-11 & 0.309 & 0.181 & 0.250 & 0.128 \\
H-12 & 0.323 & 0.187 & 0.245 & 0.136 \\
H-13 & 0.336 & 0.200 & 0.242 & 0.136 \\
H-14 & 0.322 & 0.189 & 0.241 & 0.133 \\
H-15 & 0.317 & 0.168 & 0.235 & 0.149 \\
H-16 & 0.304 & 0.166 & 0.225 & 0.138 \\
H-17 & 0.261 & 0.173 & 0.217 & 0.088 \\
H-18 & 0.258 & 0.061 & 0.158 & 0.197 \\
\hline
\end{tabular}

The variation of the average width of the ground fissure in each transverse section with depth is shown in Figure 18. The data show that, with increasing depth, the average width is relatively flat at $0 \sim 30 \mathrm{~cm}$ and decreases slowly in an approximate straight line at 30 160 cm. This trend accelerates after $170 \mathrm{~cm}$.

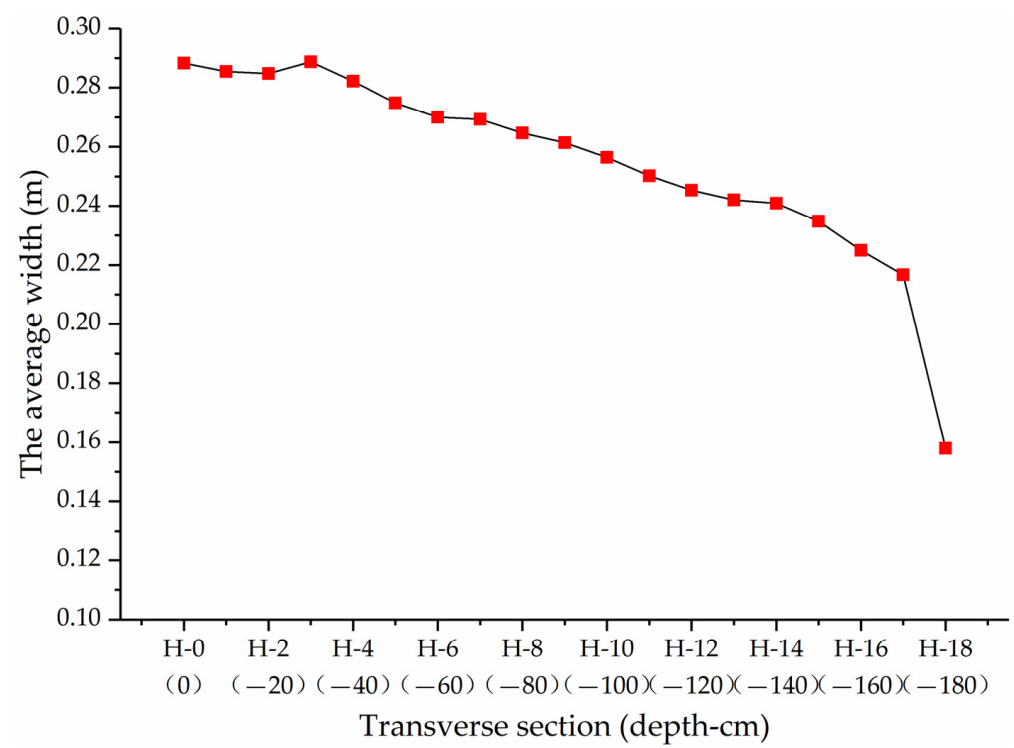

Figure 18. The variation of the average width of the ground fissure in each transverse section with depth. 


\section{Horizontal Extension Angle of the Ground Fissure}

The horizontal extension angle of the ground fissure refers to the included angle between the ground fissure and the boundary direction of the working face. It is positive to the outside of the working face and negative to the inside of the working face.

The histogram of the horizontal extension angle of the ground fissure in each transverse section varies with the direction of the working face and is constructed at intervals of $10 \mathrm{~cm}$. The angle varies in the range of $-44.88^{\circ} \sim 28.77^{\circ}$, indicating that the horizontal extension direction of the ground fissure is not strictly parallel to the boundary of the working face.

Figure 19 shows the horizontal extension angle of the ground fissure in each transverse section. The diagram documents that only one continuous position (V-10 V-18) of H-1 is biased towards the inside of the working face. Its overall direction is outside-in first, and then inside-out, and finally outside-in of the working face. Starting from H-7, the positions of V-3 and V-4 are biased towards the inside of the working face. Until H-17, two continuous positions (V-3 V-6 and V-11 V-21) are biased towards the inside of the working face. Its overall direction is outside-in first, and then inside-out, outside-in, inside-out, and finally outside-in of the working face. The data show that the horizontal extension angle of the ground fissure becomes progressively complex with increasing depth.
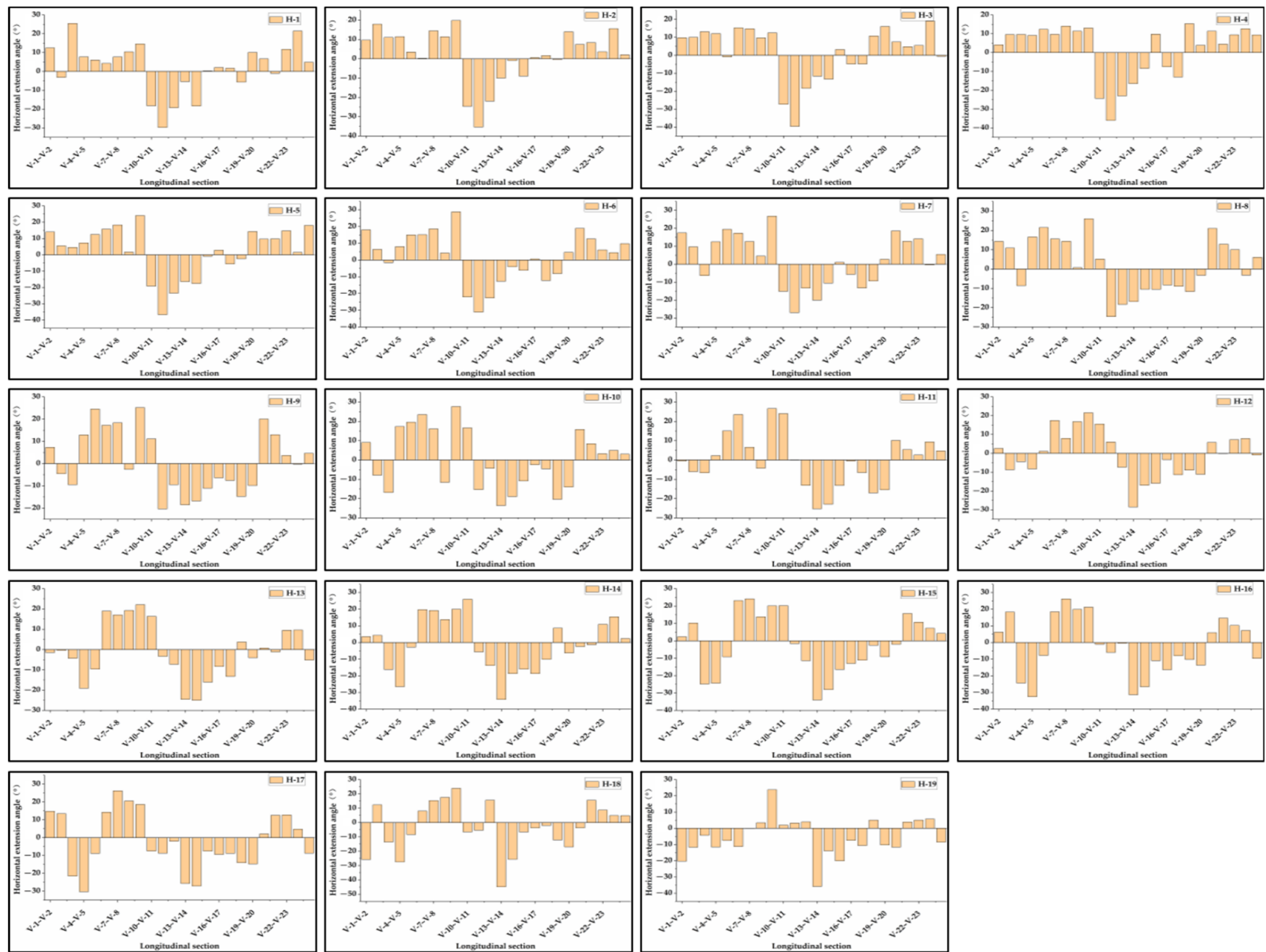

Figure 19. The horizontal extension angle of the ground fissure.

\section{Discussion}

\subsection{Complexity of Underground Morphology of Ground Fissures}

The data of ground fissures caused by single seam mining in China document that the distribution of ground fissures on the ground surface presents " $\mathrm{O}$ " rings, and that the ground fissures at the boundary of the working faces belong to permanent cracks [51]. 
However, the underground morphology of the ground fissures remained unresolved because the development of ground fissures is very complex and underground monitoring is difficult.

A comprehensive acquisition of the underground morphology of ground fissures can accurately infer the subsurface degree of their development as well as their evolution $[29,48]$. Several factors, such as the conditions of coal seam endowment, lithology and property of the roof overlying rocks, lithology of the overlying rocks, technical conditions of mining, surface topography and landforms, surface rock (soil) properties, shallow structure, weak surface conditions, and the amount of rainfall control the morphology of the ground fissures [29].

For example, the depth of ground fissures in areas with thick loess deposits can reach tens of meters, whereas ground fissures in a windy sand area are mostly thin and shallow cracks [31,51]. As the ground fissures develop downwards, they encounter the interlayer of strong-surface-weak-surface-strong-surface, and the width of the ground fissure changes abruptly [31]. The staggered distance of coal pillars can effectively inhibit the development of ground fissures [51-53].

This experiment documents an overall gradual decrease of the width of ground fissures with increasing depth, in line with the general law. However, at some specific depths, the width continuously increases. The anomalies are attributed to specific localized processes:

1. Once the ground fissure was excavated, and after the cleaning of the soil surface, we recognized a mixture of the soil surface with some fine-grained pebbles. As the pebbles are harder than the soil, they hinder the development of the ground fissure, thereby destroying the overall trend of width changes and slightly reducing the width increase at specific depth positions.

2. At a depth of 100 120 cm, a new crack developed perpendicular to the direction of the previous ground fissure at $\mathrm{V}-9-\mathrm{V}-12$, documenting a crack bifurcation phenomenon. The location and details of the crack bifurcation are shown in Figure 20. The crack bifurcation explains the abnormal value of the ground fissure width at these positions.

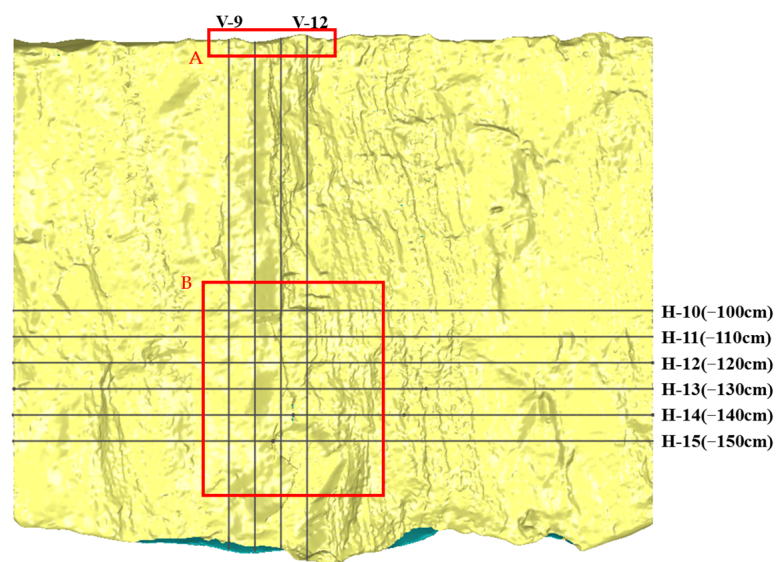

(a)

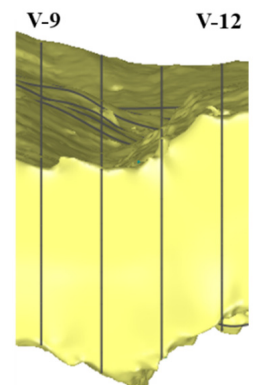

(b)

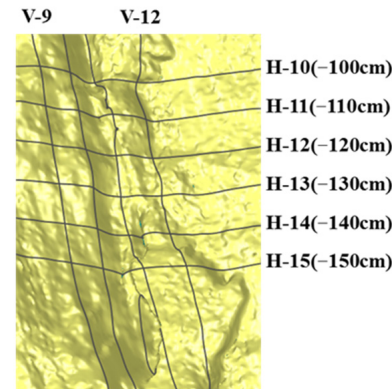

(c)

Figure 20. Location and details of the crack bifurcation: (a) Front view of crack bifurcation position; (b) Top view of position A of Figure 20a; (c) Side view of position B of Figure 20a. 
At a depth of $130 \mathrm{~cm}$, the crack bifurcation is more evolved (Figure 20c), with a tendency to separation. At $150 \mathrm{~cm}$, the separation is ultimately complete and the ground fissure forms a groove. Therefore, at depths between $130 \sim 150 \mathrm{~cm}$, the ground fissure width exhibits large variations, and at $150 \mathrm{~cm}$ the ground fissure width reaches the minimum.

The figure shows that the direction of the crack bifurcation is biased towards the inside of the working face. This is in line with the results of the analysis illustrated in Figure 19, indicating that the horizontal extension direction of the ground fissure is biased towards the inside of the working face within a distance after V-10.

\subsection{The Relationship between Ground Fissures and Coal Mining Subsidence}

Underground coal mining affects and may destroy the mechanical stability of the overlying rocks, inducing deformation of the overlying rocks and the ground. With expansion of the working face, movement and deformation of the ground surface reaches or exceeds the ultimate tensile strength, and ground fissures may occur on the ground surface [52,53]. The ground fissure starts from the surface and extends downward, and the width gradually decreases to zero.

The development of ground fissures along the vertical direction is not straight. Its bending is mainly controlled by the nature and deformation of the soil layer [54]. For a uniform soil quality and stable structure, the deformation is almost uniform in all layers. At this time, the downward extending direction of the ground fissures is biased towards the inside of the working face [55]. Otherwise, ground fissures will extend along the direction with the weaker mechanical properties, hence, the maximum deformation position of each layer [56].

Our study area is characterized by collapsible loess deposits with uniform soil quality but loose structure. Figures 15 and 16 show that the downward extension direction of the ground fissure is generally biased toward the inside of the working face, but the extension directions vary at different depth levels.

\subsection{The Particularity of Ground Fissures in Collapsible Loess Areas}

Collapsible loess has a low content of clay particles, weak cementation, small particle contact surface, mainly point contacts, and abundant pores. At dry conditions, the strength is higher. However, hydratization induced by heavy rainfall causes a significant decrease of the stability $[55,57]$. Coal mining under areas of the collapsible loess may induce the formation of ground fissure that appear on the surface. If a large amount of water during heavy rainfall invades the ground fissure, the soil on the surface will attain the bottom of the fissure as the water scours. Although the width of the fissure increases, the rainwater can transport a large amount of soil to the bottom, thereby filling the bottom. The process reduces the depth of the fissure and changes the bottom width abruptly to 0 . Thus, the morphological characteristics of the ground fissure are strongly affected.

The width change from $150 \mathrm{~cm}$ to the bottom of the ground fissure on each longitudinal section is shown in Figure 21. Except for the special longitudinal sections, V-1 (edge effect) and V-13 (crack bifurcation), the other widths vary moderately in the range of $150 \sim 170 \mathrm{~cm}$, slightly decrease at 170 180 cm, and significantly decreases at 180 200 cm. The descending range is $0.061 \sim 0.258 \mathrm{~cm}$, consistent with the landform characteristics of the collapsible loess areas.

\subsection{Deficiency of Three-Dimensional Laser Scanning Technology in Detecting Ground Fissures}

Three-dimensional laser scanning technology can completely acquire the 3D model of ground fissures, allowing the reconstruction of their formation and their development. It has a high precision and can obtain the width, depth, and extension angle of cracks at any position. However, some deficiencies exist: (1) The costs of the analysis are high, including the instrument, material costs, and labor costs [30]. (2) The experimental method used in the present study requires a ground fissure filling and excavation. The implementation process is complex and time-consuming [31]. (3) Experiments must be conducted in 
advance to determine the gypsum-water mass ratio and the time of initial and final setting [48]. (4) Ground fissure excavation inevitably destroys the development of ground fissures and the surrounding soil structure. Therefore, it is unsuitable for dynamic ground fissure monitoring [19].

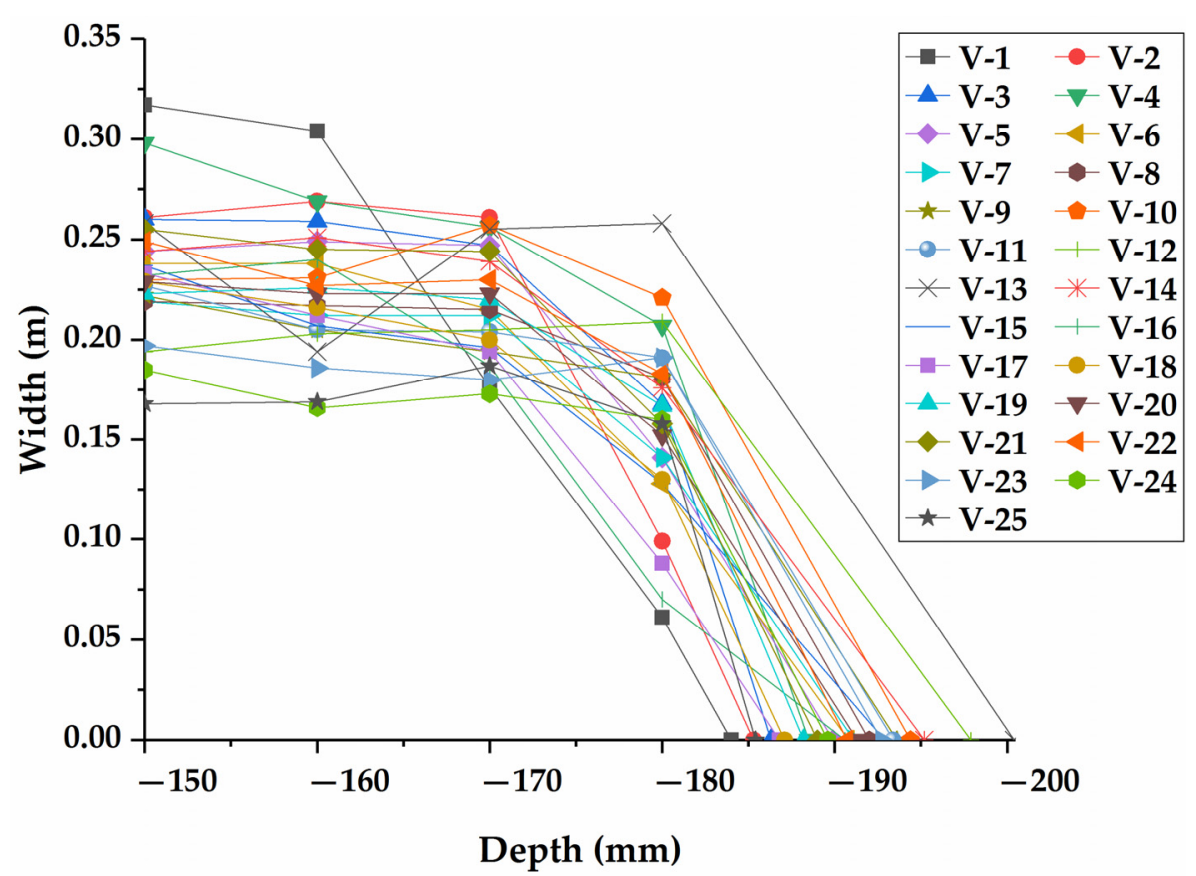

Figure 21. The width change from $150 \mathrm{~cm}$ to the bottom of the ground fissure on each longitudinal section.

To minimize the deficiencies, we propose that the gypsum-water mass ratio should be adjusted to the shape and size of the ground fissures and the soil type. Moreover, a variety of mass ratios should be determined to meet the filling requirements of different depths and widths. As the structure of soil types differs, the hardness and looseness of the respective soil type should be considered during ground fissure excavation and paste surface cleaning.

\section{Conclusions}

We studied permanent cracks with a length of about $2.5 \mathrm{~m}$ on the boundary of a collapsible loess area above the Zhangjiamao coal mine (China). An underground 3D model of ground fissures is obtained by gypsum slurry and 3D laser scanning technology, and the subsurface morphological characteristics of the fissures are studied. Our main findings are:

1. The ground fissure is cut along the horizontal and vertical directions at a distance of $10 \mathrm{~cm}$ to obtain 25 longitudinal sections and 19 transverse sections. The width is distributed between $0.061 \sim 0.358 \mathrm{~m}$, and about $80 \%$ are distributed between $0.20 \sim 0.30 \mathrm{~m}$. The vertical extension angle ranges between $-18.3^{\circ} \sim 15.5^{\circ}$ at different depth levels. The vertical overall extension angle is in the range of $-11.1^{\circ} \sim-2.6^{\circ}$. The drop is distributed between $0.3 \sim 56.4 \mathrm{~mm}$, and the range of variation is relatively large. The horizontal extension angle varies in the range of $-44.88^{\circ} \sim 28.77^{\circ}$.

2. The underground morphology of ground fissures is complex, and the width suddenly increases or decreases in specific depth layers due to the influence of the soil composition and crack bifurcation.

3. The overlying collapsible loess has a uniform lithology and loose structure, and this special soil texture causes unique ground fissures: The vertical extension direction is not regular at all levels but is biased towards the inside of the working face. With 
increasing depth, the horizontal extension direction becomes more complex, and the extension direction is not strictly parallel to the working face boundary. The bottom will be filled with loosely flowing soil, causing the bottom width to drop to 0 , which, in turn, affects the morphological characteristics.

Considering the properties of the filling materials, wider ground fissures are selected, to better obtain the gypsum of ground fissures. The finer ground fissures with shallow visible depths are not considered. Whether or not the underground 3D morphological characteristics of this type of ground fissures are in line with our conclusions will be studied in future projects.

Author Contributions: Conceptualization, Y.H., Z.H., Y.F., K.Y. and R.W.; methodology, Y.H., Z.H., Y.F., K.Y. and R.W.; software, Y.H., Y.F. and G.S.; validation, Y.H., Z.H., Y.F., K.Y. and R.W.; formal analysis, Y.H.; investigation, Y.H., Z.H., Y.F., K.Y., G.S., Z.F., Q.Y. and L.Y.; writing-original draft preparation, Y.H.; writing—review and editing, Y.H.; visualization, Y.H.; supervision, Z.H., Y.F. and K.Y.; funding, Z.H. All authors have read and agreed to the published version of the manuscript.

Funding: This research was funded by the Research and Demonstration of Key Technology for Water Resources Protection and Utilization and Ecological Reconstruction in a Coal Mining area of Northern Shaanxi; the grant number is 2018SMHKJ-A-J-03.

Institutional Review Board Statement: Not applicable.

Informed Consent Statement: Not applicable.

Data Availability Statement: Not applicable.

Acknowledgments: We thank Li Liang of China University of mining and technology for providing the 3D laser scanner. The authors would like to express their gratitude to the organization (https: / / www.editsprings.cn/ (accessed on 28 December 2021)) for the expert linguistic services provided.

Conflicts of Interest: The funders had no role in the design of the study; in the collection, analyses, or interpretation of data; in the writing of the manuscript; or in the decision to publish the results.

\section{References}

1. Wu, Q.; Tu, K.; Ceng, Y.; Liu, S. Discussion on the main problems and countermeasures for building an upgrade version of main energy. J. China Coal Soc. 2019, 44, 1625-1636.

2. BP Statistical Review of World Energy 2021. Available online: https://www.bp.com/en/global/corporate/energy-economics/ statistical-review-of-world-energy.html (accessed on 28 September 2021).

3. $\mathrm{Xu}, \mathrm{Z}$. A review on combined open-Underground mining technology in pingshuo mining area. Coal Eng. 2015, $47,11-14$.

4. Guo, J.; Liu, X.; Wang, X.; Hu, X. Mechanism of mining-induced surface destruction in metal mines and its control technology. Metal. Mine 2014, 43, 6-11.

5. Wang, H. Distribution characteristics of surface cracks in gob collapse in Xiqu mine. Min. Technol. 2006, 6, 358-359.

6. Li, Y.; Lu, G.; Wang, D.; Diao, L.; Li, C.; Dong, L.; Du, X. Morphological characteristics of ground fissures at surface coal mine dump in northern grassland of China. J. China Coal Soc. 2020, 45, 3781-3792.

7. Cheng, W.; Bian, Z.; Dong, J.; Lei, S. Soil properties in reclaimed farmland by filling subsidence basin due to underground coal mining with mineral wastes in China. T. Nonferr. Metal. Soc. 2014, 24, 2627-2635. [CrossRef]

8. Gilland, K.E.; McCarthy, B.C. Microtopography influences early successional plant communities on experimental coal surface mine land reclamation. Restor. Ecol. 2014, 22, 232-239. [CrossRef]

9. Malinowska, A.A. The impact of deep underground coal mining on Earth fissure occurrence. Acta Geodyn. Geomater. 2016, 321-330. [CrossRef]

10. Mohseni, N.; Sepehr, A.; Hosseinzadeh, S.R.; Golzarian, M.R.; Shabani, F. Variations in spatial patterns of soil-vegetation properties over subsidence-related ground fissures at an arid ecotone in northeastern Iran. Environ. Earth Sci. 2017, 76, 234. [CrossRef]

11. Pan, C.; Fan, Y.; Wang, H.; Wang, J.; Cui, S. Study on formation mechanism of ground fissures and disaster prevention and reduction measures for buildings-A case study of Qingxu area in Shanxi Province. IOP Conf. Ser. Earth Environ. Sci. 2021, 804, 22015. [CrossRef]

12. Wright, I.A.; McCarthy, B.; Belmer, N.; Price, P. Subsidence from an underground coal mine and mine wastewater discharge causing water pollution and degradation of aquatic ecosystems. Water Air Soil Pollut. 2015, 226, 3-14. [CrossRef]

13. Li, L.; Wu, K.; Chen, R.; Zhang, S. Information extraction of surface crack position in mining subsidence area based on wavelet transform. Sci. Surv. Mapp. 2010, 35, 165-166.

14. Ścigała, R.; Szafulera, K. Linear discontinuous deformations created on the surface as an effect of underground mining and local geological conditions-case study. Bull. Eng. Geol. Environ. 2020, 79, 2059-2068. [CrossRef] 
15. Kalogirou, E.E.; Tsapanos, T.M.; Karakostas, V.G.; Marinos, V.P.; Chatzipetros, A. Ground fissures in the area of Mavropigi Village (N. Greece): Seismotectonics or mining activity? Acta Geophys. 2014, 62, 1387-1412. [CrossRef]

16. Bi, Y.; Zhang, J.; Song, Z.; Wang, Z.; Qiu, L.; Hu, J.; Gong, Y. Arbuscular mycorrhizal fungi alleviate root damage stress induced by simulated coal mining subsidence ground fissures. Sci. Total Environ. 2019, 652, 398-405. [CrossRef] [PubMed]

17. Zhang, P. Study on the Impact of Coal Mining Subsidence on Soil Quality in the overlapped Areas of Cropland and Coal Resources. Ph.D. Thesis, China University of Mining and Technology-Beijing, Beijing, China, 2016.

18. Zhang, Y.; Bi, Y.; Chen, S.; Wang, J.; Han, B.; Feng, Y. Effects of subsidence fracture caused by coal-mining on soil moisture content in semi-arid windy desert area. Environ. Sci. Technol. 2015, 38, 11-14.

19. Huang, S.; Yu, X.; Zhao, X.; Fan, K. Study on mining damage law and control method of collapsible loess. Min. Saf. Environ. Prot. 2006, 33, 11-12.

20. Peng, J.; Qiao, J.; Leng, Y.; Wang, F.; Xue, S. Distribution and mechanism of the ground fissures in Wei River Basin, the origin of the Silk Road. Environ. Earth Sci. 2016, 75, 718. [CrossRef]

21. Glenn, N.F.; Streutker, D.R.; Chadwick, D.J.; Thackray, G.D.; Dorsch, S.J. Analysis of LiDAR-derived topographic information for characterizing and differentiating landslide morphology and activity. Geomorphology 2006, 73, 131-148. [CrossRef]

22. Kasai, M.; Ikeda, M.; Asahina, T.; Fujisawa, K. LiDAR-derived DEM evaluation of deep-seated landslides in a steep and rocky region of Japan. Geomorphology 2009, 113, 57-69. [CrossRef]

23. Zhang, F.; Hu, Z.; Fu, Y.; Yang, K.; Wu, Q.; Feng, Z. A new identification method for surface cracks from UAV images based on machine learning in coal mining areas. Remote Sens. 2020, 12, 1571. [CrossRef]

24. Shruthi, R.B.V.; Kerle, N.; Jetten, V. Object-Based gully feature extraction using high spatial resolution imagery. Geomorphology 2011, 134, 260-268. [CrossRef]

25. Zhao, Y.; Xu, D.; Sun, B.; Jiang, Y.; Zhang, C.; He, X. Investigation on ground fissure identification using UAV infrared remote sensing and edge detection technology. J. China Coal Soc. 2021, 46, 624-637.

26. Ye, L. Aerial Image Visual Detection and Recognition Method of Ground Crack in Goaf of Coal Mine. Master's Thesis, China University of Mining and Technology, Xuzhou, China, 2020.

27. Jia, H.; Wei, B.; Liu, G.; Zhang, R.; Yu, B.; Wu, S. A semi-automatic method for extracting small ground fissures from loess areas using unmanned aerial vehicle images. Remote Sens. 2021, 13, 1784. [CrossRef]

28. Nex, F.; Remondino, F. UAV for 3D mapping applications: A review. Appl. Geomat. 2014, 6, 1-15. [CrossRef]

29. Li, Y.; Wang, D.; Lu, G.; Diao, L.; Dong, L.; Du, X. A review of soil mass cracks characteristics and their eco-environmental effects in coal mining area. Chin. J. Ecol. 2018, 37, 3769-3779.

30. Zhang, J.; Bi, Y.; Peng, S. Study on detection methods for three-Dimensional morphology of mining-Induced ground fissures and accuracy evaluation. Coal Sci. Technol. 2020, 48, 236-242.

31. Jia, X.; Yao, H. Detection and control of ground fissure in shallow coal mining based on GPR technology. Coal Sci. Technol. 2017, $45,82-86$

32. Liu, F. Experimental Study of the Crack-depth Detection Based on the Theory of Elastic Waves. Master's Thesis, Shantou University, Shantou, China, 2009.

33. Li, W.; Liu, G.; Yao, T. Research Progress on crack characteristics of expansive soil. Adv. Sci. Technol. Water Resour. 2012, 32, 78-82.

34. Dai, H.; Luo, J.; Guo, J.; Yan, Y.; Zhang, W.; Zhu, Y. In Site surveying and study on development laws of surface cracks by high-Intensity mining in Shangwan Mine. Coal Sci. Technol. 2020, 48, 124-129.

35. Hou, E.; Xie, X.; Wang, S.; Cong, T.; Feng, D.; Chen, Z. Development law of ground cracks induced by fully-mechanized mining of medium-buried coal seams. J. Min. Saf. Eng. 2021, 38, 1178-1188.

36. Yesiller, N.; Miller, C.J.; Inci, G.; Yaldo, K. Desiccation and cracking behavior of three compacted landfill liner soils. Eng. Geol. 2000, 57, 105-121. [CrossRef]

37. Gaur, V.P.; Kar, S.K.; Srivastava, M. Development of ground fissures: A case study from southern parts of Uttar Pradesh, India. J. Geol. Soc. India 2015, 86, 671-678. [CrossRef]

38. Picornell, M.; Lytton, R.L. Field measurement of shrinkage crack depth in expansive soils. Transport. Res. Rec. 1989, 1219, 121-130.

39. Shao, G.; Du, T. Detection of shallow underground fissures by time-frequency analysis of Rayleigh waves based on wavelet transform. Appl. Geophys. 2020, 17, 233-242. [CrossRef]

40. Hu, Z.; Wang, X.; He, A. Distribution characteristic and development rules of ground fissures due to coal mining in windy and sandy region. J. China Coal Soc. 2014, 39, 11-18.

41. He, Y.; Hu, Z.; Wu, K.; Wang, R. A novel method for density analysis of repaired point cloud with holes based on image data. Remote Sens. 2021, 13, 3417. [CrossRef]

42. Gong, Z. Research on Point Cloud Processing Method of 3D Laser Scann Technology. Ph.D. Thesis, China University of Geosciences, Wuhan, China, 2017.

43. He, Y. Technical Research on Mending Three-Dimensional Point Cloud Holes with Images. Master's Thesis, China University of Mining and Technology, Xuzhou, China, 2018.

44. He, Y.; Cai, J.; Wang, J.; Yu, Z.; Guan, Z.; Zhou, D. Modeling and repairing of ancient city wall by three-dimensional laser scanning technology. Laser J. 2018, 39, 85-89.

45. Zhou, J. Forest Parameter Extraction from Terrestrial Laser Scanning Data. Ph.D. Thesis, University of Electronic Science and Technology of China, Chengdu, China, 2019. 
46. Duan, Y. Three-Dimensional Reconstruction of Outdoor Scenes Based on Laser Point Clouds. Master's Thesis, Dalian University of Technology, Dalian, China, 2021.

47. Chu, H.; Xing, G.; Li, K.; Wang, G.; Duan, Q. Monitoring of dangerous rock mass in the Three Gorges Reservoir area based on the terrestrial laser scanning method. Hydrogeol. Eng. Geol. 2021, 48, 124-132.

48. Wang, X. Monitoring, Evolution and Self-Healing Characteristics of Land Damage Due to High Tension Coal Mining in Windy and Sandy Area. Ph.D. Thesis, China University of Mining and Technology-Beijing, Beijing, China, 2014.

49. Peng, J. Research on Registration and Reconstruction of 3D Point Cloud Scene. Master's Thesis, Southwest University of Science and Technology, Mianyang, China, 2020.

50. He, Y.; Chen, R.; Wu, K.; Duan, Z. Point cloud simplification method based on k-means clustering. Laser Optoelectron. Prog. 2019, $56,96-99$.

51. Cao, J.; Huang, Q. Rregularity and control of overburden and surface fractures in shallow-contiguous seams. Coal Geol. Explor. 2021, 49, 213-220.

52. Hu, Q.; Cui, X.; Yuan, D.; Deng, X. Formation mechanism of surface cracks caused by thick seam mining and hazard analysis. J. Min. Saf. Eng. 2012, 29, 864-869.

53. Wang, J.; Zhao, H.; Liu, J. Study on dynamic law of surface movement above working face of shallow-Buried coal seam with thin bedrock. Min. Saf. Environ. Prot. 2016, 43, 21-25.

54. Wu, K.; Zhou, M.; Hu, Z. The prediction of ground fissure depth and width by mining. J. Fuxin Min. Inst. 1997, 16, 649-652.

55. Ma, X.; Bai, Z.; Shao, Y.; Zhang, S.; Wu, J.; Zhao, M. Eco-Environmental impact assessment on subsidence with coal mining in loess hilly areas-Taking kaiyuan mine of yangquan coal limited company as example. J. Shanxi Agric. Univ. 2004, $24,47-51$.

56. Wu, K.; Li, L.; Ao, J.; Hao, G. Discussion on limit development depth of cracks in surface soil mass caused by mining subsidence. Coal Sci. Technol. 2010, 38, 108-111.

57. Pang, Z. Research on Bearing Behavior of Composite Foundation in Collapsible Loess Area. Master's Thesis, China University of Geosciences, Beijing, China, 2020. 